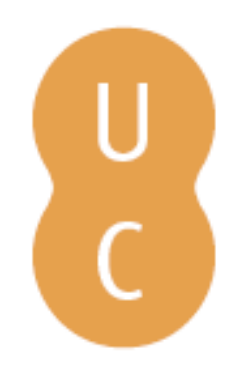

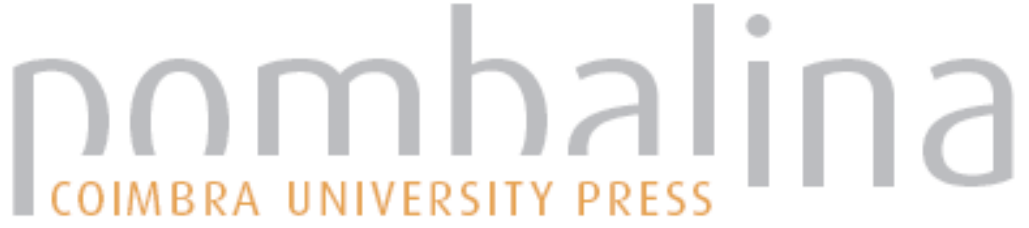

\section{As ciências físico-matemáticas em Portugal e a reforma pombalina}

\author{
Autor(es): $\quad$ Martins, Décio Ruivo
}

Publicado por: Imprensa da Universidade de Coimbra

URL

persistente:

URI:http://hdl.handle.net/10316.2/31951

DOI:

DOI:http://dx.doi.org/10.14195/978-989-26-0753-5_7

Accessed : $\quad$ 26-Apr-2023 13:42:10

A navegação consulta e descarregamento dos títulos inseridos nas Bibliotecas Digitais UC Digitalis, UC Pombalina e UC Impactum, pressupõem a aceitação plena e sem reservas dos Termos e Condições de Uso destas Bibliotecas Digitais, disponíveis em https://digitalis.uc.pt/pt-pt/termos.

Conforme exposto nos referidos Termos e Condições de Uso, o descarregamento de títulos de acesso restrito requer uma licença válida de autorização devendo o utilizador aceder ao(s) documento(s) a partir de um endereço de IP da instituição detentora da supramencionada licença.

Ao utilizador é apenas permitido o descarregamento para uso pessoal, pelo que o emprego do(s) título(s) descarregado(s) para outro fim, designadamente comercial, carece de autorização do respetivo autor ou editor da obra.

Na medida em que todas as obras da UC Digitalis se encontram protegidas pelo Código do Direito de Autor e Direitos Conexos e demais legislação aplicável, toda a cópia, parcial ou total, deste documento, nos casos em que é legalmente admitida, deverá conter ou fazer-se acompanhar por este aviso.

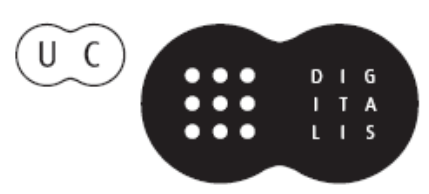



(Página deixada propositadamente em branco) 
AS Cî̂nCIAS Físico-MATEMÁTICAS

EM PORTUGAL E REFORMA POMBALINA

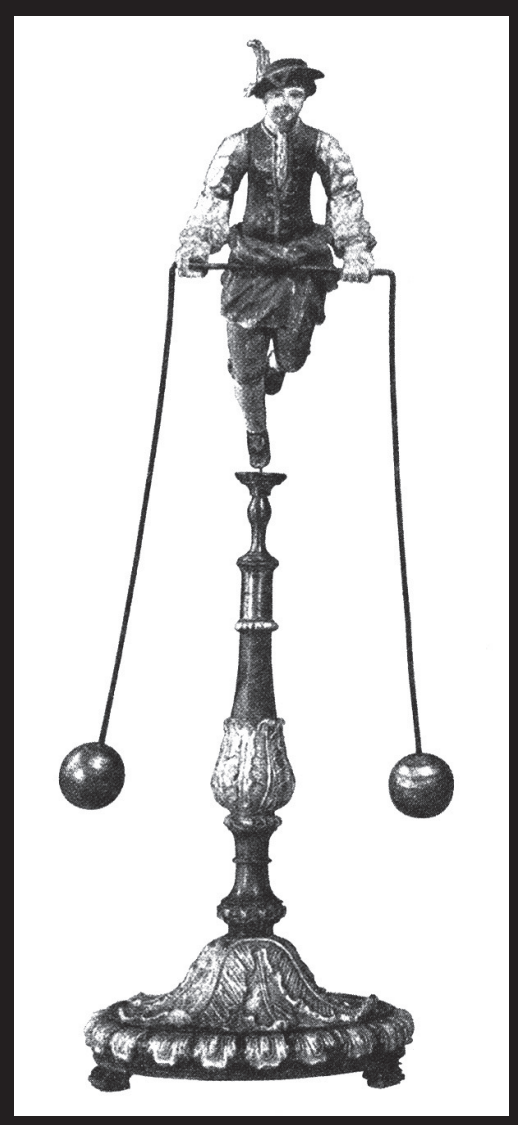


Equilibrista ilustrando a condição de equilíbrio, séc. XVIIIl, Museu de Física da Universidade de Coimbra

foto: José Pessoa, Divisão de Documentação Fotográfica do IPM 


\section{AS C I ÊNCIAS FíSICO-MATEMÁTICAS EM PORTUGAL EA REFORMA POMBALINA}

\section{As ciências físico-matemáticas em Portugal antes de 1772}

Em vários documentos relativos à Reforma Pombalina da Universidade de Coimbra ficaram inequivocamente expressas opiniões extremamente críticas em relação à natureza e qualidade do ensino das ciências físico-matemáticas em Portugal antes de 1772. Toda a actividade pedagógica e científica que antecedeu este movimento renovador foi criticada de uma forma veemente, argumentando-se que o ensino até então praticado na generalidade das escolas era caracterizado por uma lamentável e repreensível insciência, com repercussões muito negativas na cultura científica portuguesa da época. A responsabilidade deste alegado obscurantismo científico foi, durante um período muito conturbado da vida social e cultural, atribuída prioritariamente e de um modo indiscriminado aos jesuítas. Estes foram acusados de serem completamente ignorantes das novas correntes de pensamento científico e filosófico que dominavam a cultura europeia no século do iluminismo, sendo identificados, de um modo geral, com os sectores mais retrógrados da cultura portuguesa. Para além desta ausência de cultura científica, também foram responsabilizados por promoverem uma prática pedagógica intencionalmente obstrucionista, na qual a autoridade do nome de Aristóteles era a referência absoluta. A Companhia de Jesus detinha a primazia do ensino no país.

\footnotetext{
* Faculdade de Ciências e Tecnologia da Universidade de Coimbra. Centro de Física Computacional.
} 
O seu projecto de ensino foi considerado o principal entrave do desenvolvimento científico e tecnológico português. De acordo com os ideólogos e promotores da Reforma Pombalina dos estudos, a Filosofia, que até então oficialmente se ensinava, mantinha uma influência profunda e decadente da Escolástica. Segundo esta perspectiva, os temas de ensino eram exclusivamente dominados pelos arcaicos dogmas peripatéticos. Para além dos professores jesuítas terem sido genericamente acusados de seguirem de um modo inflexível as ideias aristotélicas, também foram duramente censurados por não se isentarem em absoluto de um condenável e estéril confronto com outros tipos de saber, originados da praxis ou experiência científica. Alegadamente, esta atitude pedagógica teve consequências profundamente nefastas na formação intelectual da juventude. O ensino das ciências, tal como se afirmava explicitamente nos Estatutos Pombalinos, era considerado miserável. Uma das críticas mais intensamente expressas era que a aquisição do conhecimento mantinha uma dependência improfícua em relação a um saber sobretudo literário. A actividade intelectual era considerada acessível apenas àqueles que, livres de ocupações materiais, podiam dedicar-se à leitura das grandes obras do passado, cujo conteúdo se limitava unicamente à espúria Filosofia Antiga. Deste modo, o conhecimento oficialmente difundido nas instituições de ensino era considerado retrógrado e obsoleto.

No entanto, uma análise da actividade pedagógica observada nalgumas escolas mais prestigiadas permite encontrar alguns indicadores de que a cultura científica portuguesa, no período anterior a 1760, estaria longe de se caracterizar pelo panorama absolutamente miserável, como o apresentado pelos ideólogos da Reforma Pombalina. Qualquer análise objectiva das características e qualidade do ensino dos temas científicos, contemplados nos cursos de Filosofia, Matemática e Astronomia que pretenda avaliar o nível científico dos jesuítas deverá ser feito de um modo integrado, tendo como referência as suas principais escolas em Portugal. A importância desta análise justifica-se pela mobilidade dos docentes, e nalguns casos dos estudantes, que frequentemente mudavam de estabelecimento de ensino, normalmente em ciclos de três anos, correspondentes ao tempo de leccionação de um curso completo. Esta 
mobilidade, que conferia às principais escolas jesuítas um certo carácter de complementaridade científica e pedagógica, foi sempre uma constante desde o início do século XVII e manteve-se até 1759.

Desde a época contemporânea de Galileu, as escolas jesuítas que mais destaque tiveram no ensino em Portugal foram o Colégio de Santo Antão em Lisboa, o Colégio das Artes em Coimbra e a Universidade de Évora. ${ }^{1}$ Alguns estudos realizados sobre a actividade pedagógica dos jesuítas fazem notar que no Colégio das Artes não foi fácil admitir oficialmente o ensino das novas tendências científicas e filosóficas, sobretudo por motivos extrínsecos de outra ordem, que nada tinham a ver com as convicções ou com a competência científica e pedagógica de vários dos seus professores. ${ }^{2} \mathrm{Na}$ verdade, uma das razões fundamentais para um pretenso défice de desenvolvimento e de modernidade científica e pedagógica que oficialmente caracterizavam os seus cursos era de natureza estatutária. Com efeito, os decrépitos Estatutos Universitários, pelos quais se regia o Colégio, impunham de um modo inflexível que se seguissem Aristóteles e as linhas mais clássicas do pensamento nos cursos que nesta escola eram professados. Nos Estatutos da Universidade de Coimbra de 1653, que vigoraram até 1772 , podemos ler o seguinte: 3

Das cadeiras \& leituras das Artes.

Averá sempre quatro cursos em Artes, que lerão quatro Lentes. E cada curso será de trez annos, \& seis mezes: começando cada anno hũ curso do principio de Outubro, \& achandose o derradeiro no fim de Março: \& no ler delle se terá esta ordem.

I. No primeiro anno se lerá Logica.

\footnotetext{
1 Décio R. Martins, Aspectos da Cultura Científica Portuguesa até 1772. (Dissertação de Doutoramento), Departamento de Física, Universidade de Coimbra, Coimbra, 1997.

${ }^{2}$ L. Craveiro Silva, "Inácio Monteiro - significado da sua vida e da sua obra". Revista Portuguesa de Filosofia, Tomo XXIX, Julho-Setembro de 1973, Fasc. 3, p. 231.

3 ESTATUTOS da Universidade de Coimbra confirmados por El Rey nosso Snor Dom João o $4^{\circ} \mathrm{em}$ o anno de 1653. Impressos por mandado e orde de MANOEL DE SALDANHA do Conselho de Sua Magestade Reitor da mesma Vniuersidade e Bispo eleito de Viseo. Em COIMBRA com as licenças Officina de Thome Carualho impressor da Uniuersidade. Anno 1654 , p. 235.
} 
. Introducção, Predicaueis de Porphyrio, Predicamentos, \& Perihermenias de Aristoteles: no segundo anno Priores, o que for necessario, Posteriores, Topicos, Elenchos, \& seis liuros dos Physicos de Aristoteles. No terceiro anno, dous dos Physicos q ficão, os de Colo, a Metaphysica, Metauros, \& Paruos naturaes de Aristoteles. No quarto os de Generatione, \& os de Anima, \& das Ethicas, o que for mais necessario, não se trattando ex professo da doutrina da Primeira, \& Segunda de S. Thomas. E porem pera as ditas Ethicas, poderá o Mestre escolher o ditto tempo, ou o fim do segundo anno.

II. Em todos estes annos lerão sempre os Mestres o texto de Aristoteles, dando as glosas que lhe parecer.

Com efeito, as determinações estatutárias constituíram um factor fundamental que, durante mais de um século, condicionou intensamente qualquer tentativa de inovação pedagógica. Esta situação limitativa, no entanto, não era do inteiro agrado daqueles professores que pretendiam rever e actualizar o seu ensino, desejando progredir particularmente nas ciências e admitir oficialmente nas suas aulas o estudo de novos pensadores. Dentro destes novos horizontes se desencadeou um plano geral de renovação no ensino da Filosofia nos Colégios da Companhia de Jesus, que constituiu uma espécie de manifesto oficial das novas tendências no ensino de Coimbra e Évora.

A maior oposição encontrada pelos jesuítas em relação a qualquer tentativa de remodelação do ensino no curso de Filosofia verificou-se no Colégio das Artes. Um dos factores condicionantes desta intenção de modernização do ensino, observado ainda na primeira metade do século XVIII, veio directamente do Rei. Esta ocorrência deu-se numa época em que a Filosofia newtoniana se afirmava em toda a Europa e esboçava os primeiros passos em Portugal. No ano de 1712 foi dirigido a D. João V um pedido, precisamente pelos professores de Coimbra, solicitando autorização para introduzir uma alteração no Curso de Filosofia do Colégio das Artes. A mudança proposta deveria ser oficializada através de uma revisão dos obsoletos Estatutos da Universidade. Tal intenção inovadora tinha como objectivo fundamental a ampliação do estudo da Física. Para o efeito, era apresentado como motivo justificativo o facto desta Ciência se 
ter acrescentado notavelmente com as experiências modernas, muito mais do que anteriormente. $\mathrm{O}$ pedido foi indeferido pelo monarca, mandando intimá-lo, pelo Reitor da Universidade, ao Reitor do Colégio, P.e Domingos Nunes. O teor da Provisão de D. João V, de 23 de Setembro de 1712 era o seguinte: ${ }^{4}$

Dom Joaó por graça de Deos Rey de Portugal, e dos Algarves, da Quem e da Lem Mar em Africa S. ${ }^{\text {or }}$ de Guinné \&. ${ }^{a}$ Como Protector que sou da Vn. de de Coimbra Faço Saber a vós Dom Gaspar de Moscoso e Silva do meu Con. ${ }^{\circ}$, meu submilher da Cortina, e Reytor da mesma Vn. de que por haver noticia no meu Tribunal da Meza da Cons. ${ }^{\text {cia }}$ e Ordens que no Coll. ${ }^{\circ}$ da Companhia dessa Cidade se quer introduzir nas Cadeiras de Filozofia outra forma de Licaõ da que athegora se observava, e mandaõ os estatutos. Hey por bem, e vos mando que havendo nesta materia alguã alteraçaõ a façais evitar, fiando de vosso Zello naõ consintais esta nova introduçaõ, e do que neste particular houver me dareis Conta pello dito Tribunal por maõs do meu Escrivaõ da Cam. ${ }^{\text {ra }}$, e do desp. ${ }^{\circ}$ delle que esta sobscrevo. El Rey nosso S. ${ }^{\text {or }}$ o mandou pl. ${ }^{\text {os }}$ DD. Antonio de Freitas Soares, e Dom Francisco de Souza Deputados do desp. ${ }^{\circ}$ do Tribunal da Meza da Consciencia, e ordens. João Correa e fes em Lx. ${ }^{a}$ a 23 de Setro de 1712. Manoel Teix. ${ }^{\text {ra }}$ de Carualho a fez escreuer An. ${ }^{\text {to }}$ de Freitas Soares Dom Francisco de Souza Por desp. ${ }^{\circ}$ da Meza da Cons. ${ }^{\text {cia }}$ e ordenz de 23 de Setr. $^{\circ}$ de 1712.

Alguns anos mais tarde o mesmo condicionalismo foi reafirmado no Edital do Reitor do Colégio das Artes de Coimbra, de 7 de Maio de 1746.5 Após a recusa para o pedido de alargamento do ensino da Física no curso

${ }^{4}$ Arquivo da Universidade de Coimbra; provisões - Vol. 5, fls. 32. Este documento foi publicado por Teófilo Braga, na História da Universidade de Coimbra, - Tomo III, p. 298. - e por Joaquim de Carvalho no Boletim da Biblioteca da Universidade de Coimbra, Vol. XX, 1951, p. 169.

5 Arquivo da Universidade de Coimbra - provisões - Vol. 5, fls. 145. Este documento foi publicado no Anuário da Universidade de Coimbra de 1880-1881, p. 238, integrado nas Memórias da Universidade de Coimbra, de Carneiro de Figueiroa, e também por Joaquim de Carvalho no Boletim da Biblioteca da Universidade de Coimbra, Vol. XX, 1951, p. 170-172. 
de Filosofia, verificada em 1712, nova restrição viria a ser imposta ao desenvolvimento do ensino das matérias físico-matemáticas. Com efeito, o Reitor do Colégio das Artes ordenou, em 7 de Maio de 1746, que fosse afixado um longo edital que estabelecia algumas restrições nesta escola. Entre as muitas deliberações havia uma alínea que vetava a abordagem de assuntos de carácter científico nas aulas, deixando bem expressa a proibição da defesa das opiniões de filósofos modernos. O referido impedimento verificou-se particularmente nos temas relacionados com a Física. No Edital podia ler-se que:

...nos exames, ou Lições, Concluzões publicas, ou particulares se-não insine defençaõ ou opinioes novas pouco recebidas, ou inuteis p. ${ }^{\circ}$ o estudo das Sciencias mayores como saõ as de Renato Descartes, Gacendo, Neptono, e outros, e nomeadam.te qualquer Sciencia, q. defenda os actos de Epicuro, ou negue as realid.es dos accidentes Eucharisticos, ou outras quaisquer concluzõis oppostas ao sistema de Aristoteles, o qual nestas escólas se-deve seguir, como repetidas vezes se-recomeda nos estatutos deste Collegio das-Artes.

O extenso documento revelou-se um facto histórico ao qual foi dado uma importância notável porque, entre as muitas determinações nele contidas, a imposição restritiva em relação aos autores e filósofos modernos, tornada pública pelo Reitor, foi interpretada como uma conduta obstrucionista generalizada dos jesuítas do Colégio das Artes em relação ao ensino das ciências em geral e da Física em particular. Nas análises históricas que posteriormente se fizeram, a escola de Coimbra passou a ser identificada com o sector mais retrógrado da cultura científica portuguesa e foi classificada como o mais influente bastião da Filosofia peripatética em Portugal. Particularmente os jesuítas que ensinavam naquele Colégio foram acusados indiscriminadamente de combaterem ferozmente qualquer intuito renovador da actividade científica e pedagógica nas escolas portuguesas até à sua expulsão de Portugal. Na verdade, a determinação restritiva em relação ao ensino de temas científicos modernos, inserida num conjunto numeroso de normas gerais estabelecidas com o intuito 
de regulamentar toda a actividade dos docentes e estudantes, tem sido frequentemente utilizada como argumento fundamental para denegrir de um modo generalizado e indiscriminado todo o desempenho pedagógico dos jesuítas no Colégio das Artes. No entanto, a proibição formalizada em termos tão vigorosos permite supor como verosímeis os factos indicadores de que a sua redacção e inclusão naquele documento só se justificava porque, na realidade, os temas da Filosofia Moderna, e particularmente da Filosofia newtoniana, já constituíam objecto de análise nas aulas daquele Colégio, embora não oficialmente. Caso se tivesse verificado uma cega e inerte obediência às imposições estatutárias e se a Provisão de D. João $V$ de 1712 tivesse produzido os efeitos condicionantes pretendidos, não teria sido necessária a funesta e lamentável intervenção censória do Reitor do Colégio. A interpretação dos factos permite que se admita que, apesar de todas as vicissitudes, alguns professores pretendiam promover o ensino das matérias científicas de um modo mais adequado à modernidade da época. O facto de, naquele documento, o Reitor do Colégio decretar de modo tão explícito a proibição do ensino, ou defesa das opiniões novas ou pouco recebidas, ou inúteis para o estudo das ciências, como eram consideradas as de Descartes, Gassendi, Newton, entre outros, teria constituído um grande obstáculo para o pretendido desenvolvimento do ensino naquela escola de Coimbra, não fosse a obstinação de algumas mentes menos empedernidas e espíritos independentes.

Apesar da importância que lhe tem sido dada, servindo como argumento fundamental para se pretender demonstrar o pretenso obscurantismo cultural e a sua influência decisiva como factor de entrave ao desenvolvimento científico reinante em Portugal, cuja responsabilidade foi particularmente atribuída aos jesuítas, o parágrafo do Edital de 1746 não constituiu, na verdade, um argumento suficientemente forte para estancar definitivamente os propósitos latentes de renovação científica e pedagógica no Colégio das Artes. A veemência da intervenção restritiva do Reitor não foi suficiente para provocar a apatia dos que pretendiam dar ao ensino das matérias científicas um dinamismo reconhecidamente moderno. Alguns anos mais tarde, surgiram novas propostas de reforma do Curso de Filosofia. Uma das medidas mais importantes preconizadas 
neste novo projecto de reestruturação era a da modernização do ensino das matérias científicas, reforçando-se particularmente a imperiosa necessidade do desenvolvimento de temas na área da Física. Este projecto, apesar de substancialmente inovador em relação ao obsoleto programa de estudos oficialmente impostos pelos caducos Estatutos da Universidade e indiferente aos vários aspectos condicionantes dos intentos renovadores, não deixava, no entanto, de ser moderado e cauteloso. O Elencus Quaestionum, quae a Nostris Philosophice Magistris debent, in hac Provincia Lusitana Societatis Jesu, ${ }^{6}$ redigido no ano de 1754 , pode ser considerado uma referência importante para a História do Ensino em Portugal. Um dos seus aspectos mais significativos traduzia-se na perspectiva moderna proposta para o ensino das matérias relacionadas com a Física. Com efeito, o Elencus Quaestionum deve ser entendido como um projecto pedagógico dos jesuítas do Colégio das Artes, através do qual se pretendia uma verdadeira renovação do ensino da Filosofia em geral, com repercussões significativas no ensino da Física em particular. Nos devastadores anos do final da década de cinquenta este programa de ensino acabou por ficar escondido numa pequena biblioteca das freiras do Convento de Santa Maria de Semide. ${ }^{7}$ O manuscrito não era mais do que um plano de estudos de Filosofia, onde se tornava notório um ecletismo equilibrado, perante a revolução científica que se operava nos centros cultos da Europa. Se por um lado conservava os princípios metafísicos do ser, rejeitava, no entanto, a apresentação metafísica das questões Físicas. O conteúdo programático do Elencus contemplava o estudo dos autores antigos e modernos que se distinguiram para o desenvolvimento da Física, embora, conforme o consenso geral sobre o Universo, fosse proposto o sistema aristotélico, seguindo-se sobretudo a orientação de S. Tomás. A refutação dos demais sistemas deveria ser feita sem sarcasmos e tendo sempre em conta as modernas experiências que concordavam com os princípios aristotélicos. Esta moderação não

6 ANTT - Impressos da Livraria, 4370 da série preta.

7 A. Banha de Andrade, "Elencus Quaestionum de 1754." Revista Portuguesa de Filosofia, Tomo XXII, 1966, p. 258. 
era tão acentuada nos temas da área da Física. O estudo da gravidade deveria ser feito com base na explicação das opiniões peripatética, cartesiana e newtoniana, propondo-se a adopção da que se mostrasse mais próxima da verdade. Estudos sobre a velocidade e quantidade de movimento teriam como base o louvável método dos modernos. No que respeita ao estudo do corpo elástico propunha-se a apresentação dos modelos de Descartes, Gassendi e Newton. A Física particular deveria ocupar-se do mundo em geral, onde eram apresentadas as opiniões de Aristóteles, Descartes, Kepler, Newton. O estudo dos quatro elementos seria feito com referência ao tubo de Torricelli, às esferas de Magdeburgo e às opiniões de Descartes, Gassendi e Borelli. Estes assuntos seriam sucedidos pelo estudo do Magnetismo, Electricidade, Geografia e seus problemas de longitude e latitude, zonas, climas, origem dos montes, rios, fontes, termas, águas minerais, salsugem e cor das águas do mar, fluxo e refluxo, etc...

No período de afirmação de novas ideias entre os jesuítas portugueses evidenciou-se, em Coimbra, um exemplo bem relevante de uma profunda reflexão sobre a nova cultura científica europeia. Precisamente no ano de 1754, apareceu publicado no Colégio das Artes o primeiro volume do Compendio dos Elementos de Mathematica, da autoria de Inácio Monteiro. O segundo volume sairia publicado em 1756. Nesta obra que, apesar do nome, deve ser considerada um Compêndio de Física, o seu autor revelava um assinalável conhecimento das novas perspectivas científicas e pedagógicas europeias da época. As melhores referências bibliográficas que viriam a ser utilizadas por Dalla Bella na organização da cadeira de Fysica Experimental, em 1772, já eram utilizadas e recomendadas por Inácio Monteiro nas suas lições no Colégio das Artes. ${ }^{8} \mathrm{O}$ Compêndio dos Elementos de Mathematica tornou-se uma referência preferencial sobre as características do ensino da Filosofia e da Ciência Moderna posto em prática no Colégio das Artes em Coimbra, mais de vinte anos antes da Reforma Pombalina. Craveiro da Silva deixou expressa a opinião de que Inácio Monteiro foi uma das figuras centrais na evolução da cultura

\footnotetext{
8 Décio R. Martins, ob. cit.
} 
portuguesa na segunda metade do século XVIII. ${ }^{9}$ Por sua vez, A. Banha de Andrade afirmou ter sido Inácio Monteiro o professor mais bem informado do movimento científico e, porventura, filosófico, dentre os jesuítas dessa época. ${ }^{10}$ Tal como afirmou J. Pereira Gomes, a obra literária de Inácio Monteiro, pela sua maior parte escrita na década de 1750-1760, distinguia-se pela clareza, método, erudição e modernidade das ideias, constituindo uma das expressões mais altas da cultura portuguesa nesse período. ${ }^{11}$ Uma análise pormenorizada das suas principais obras deixa antever que Inácio Monteiro foi um professor jesuíta que, cerca de duas décadas antes da Reforma Pombalina da Universidade de Coimbra, delineou um projecto de ensino que revelava um notável carácter de inovação e modernidade pedagógica e científica. Os aspectos da complementaridade da formação teórica e experimental dos estudantes encontravam-se bem patentes no seu projecto educativo. A sua atitude pedagógica moderna e bem esclarecida era tornada evidente no primeiro volume do Compendio dos Elementos de Mathematica, publicado em Coimbra, no Colégio das Artes, no ano de 1754 , quando afirmava que ${ }^{12}$ :

Ninguem ignora que nenhum homem no mundo pode hoje aprender Philosophia sem intelligencia da Mathematica. A Physica verdadeira e que nestes tempos se cultiva, naõ saõ entes de razaõ, as possibilidades, e chymeras dos antigos, ociosas sutilezas do entendimento humano. Estudamos hoje a natureza pela observaçaõ e pelo cálculo; os entes da razaõ naõ se medem pela Geometria; porém esta sciencia he o fundamento dos conhecimentos physicos que fazem o corpo da Philosophia moderna. Hum Cartesiano e Gassendista, que naõ sabe Geometria, ignora com esta a sua mesma doutrina. Pertender estudar Physica experimental sem Mathematica he querer ensinar Teologia ignorando o Cathecismo.

9 L. Craveiro Silva, "Inácio Monteiro - significado da sua vida e da sua obra". Revista Portuguesa de Filosofia, Tomo XXIX, Julho-Setembro de 1973, Fasc. 3. p. 229.

10 A. Banha de Andrade, Verney e a Cultura do seu tempo. Coimbra, 1966, p. 242.

11 J. Pereira Gomes, Verbo Enciclopédia Luso-Brasileira de Cultura, Vol. 13, Col. 1279.

12 Inácio Monteiro, Compendio dos Elementos de Mathematica. Coimbra, Real Collegio das Artes da Companhia de Jesus, 1754, Tomo I, Prólogo ao Leitor, p. 4-5. 
Para quem tivesse a intenção de incluir Inácio Monteiro numa escola filosófica obsoleta, caracterizada pelo dogmatismo retrógrado e pela cega obediência à autoridade aristotélica imposta pelos arcaicos Estatutos Universitários, o jesuíta respondeu de uma forma clara no prefácio da Philosophia Libera seu Ecletica ao afirmar: 13

Já desde o início, mas sobretudo a partir de Descartes até agora, passou a Filosofia por muitas e variadas vicissitudes e mudou de indumentária, como se fosse personagem teatral a entrar em cena. Ainda mesmo agora, nem todos estão de acordo sobre a Escola que se deva proferir. Dentro desta variedade de preferências, uns há que defendem a todo o transe Aristóteles; outros preferem a Aristóteles Epicuro, Príncipe dos Atomistas; muitos abandonam completamente os acampamentos Gregos, sacodem o jugo servil de tantos anos e fazem de Descartes objecto único das suas delícias, escolhendo-o como guia filosófico. Por outro lado, Newton, digno da estirpe e do talento de Descartes e seu rival na erudição, arrebatou-lhe grande número de adeptos e, até, uma nação inteira; mas não faltou quem, como Leibniz, fizesse guerra a Newton, fundando nova escola.

A sua formação académica em Évora foi muito influenciada pela orientação peripatética da Filosofia perfilada por alguns dos seus mestres. No entanto, o seu espírito livre e crítico levou-o a evoluir no sentido da adopção da Filosofia Moderna. Sobre o caminho que haveria de seguir, Inácio Monteiro afirmou a sua preocupação em manter o espírito aberto e bem isento a respeito de Aristóteles, pois neste havia muitas coisas que o não satisfaziam. Afirmou que por isso teria passado de um Grego para outro Grego, de Aristóteles para Epicuro, através da tradução latina de Gassendi. Mantendo-se fiel às palavras de S. Agostinho: Acreditai no que Agostinho prova, e não no que Agostinbo diz, acabou por deixar Epicuro

13 Inácio Monteiro, Philosophia Libera seu Ecletica. Veneza, 1772, Tomo II, $2^{\text {a }}$ Ed., Praefatio ad Lectorem, (Tradução), Revista Portuguesa de Filosofia, Tomo XXIX, Julho-Setembro de 1973, Fasc. 3, p. 318-322. 
e o sistema dos Atomistas, em relação ao qual declarava não concordar em muitos pontos; aplicou-se ao estudo do sistema cartesiano e à nova Filosofia, servindo-lhe de guia a Geometria e a Astronomia, considerando-as a natureza da Física moderna ${ }^{14}$. Nem mesmo com Descartes encontrou respostas para as suas dúvidas. Inácio Monteiro afirmou que depois de ter lido Descartes, lhe ficou a opinião de que este tinha resvalado para o campo imenso das hipóteses, vendo na sua Filosofia algo em que tudo era apresentado engenhosamente, onde considerava muitas coisas verdadeiras, e muitas também claramente falsas. Inácio Monteiro declarou que:

Ao ler com atenção e ao discorrer pela teoria cartesiana do mundo e na primeira construção de tão grandiosa obra, segundo as ideias desse autor, pensava ler coisa bem diferente de uma elegantissima fábula ou um poeta a filosofar. Mandei, portanto, passar Descartes, Gassendo, Epicuro e Aristóteles, pelo menos por algum tempo, e peguei em Newton. Reflecti, depois, o melhor que pude, sobre a doutrina newtoniana, isto é, sobre a subtilissima Geometria aplicada ao sistema das revoluções celestes e a muitissimos fenómenos naturais por meio da atracção universal; comparei com os demais sistemas filosóficos, por mim percorridos com prazer e paixão; vi-me, ora peripatético, ora atomista, cartesiano e newtoniano; e feita tão arriscada experiência, entendi que todos eles ensinavam algumas verdades, que muitissimas coisas eram duvidosas e falsas, e que a verdade não era apanágio de nenhum sistema.

Pela actividade que desenvolveu no ensino em Coimbra, bem como pela importância da obra de literatura científico-pedagógica que deixou em Portugal, antes da sua prisão e expulsão do país, merece que seja dado o devido destaque a Inácio Monteiro. Com efeito, tratou-se de um professor jesuíta que, ainda jovem, no Colégio das Artes começou a evidenciar uma notável cultura científica. Todas a expectativas que nele se colocavam como pedagogo e como autor literário, foram confirmadas pela importante acção que desenvolveu em Itália, principalmente na

\footnotetext{
${ }^{14}$ Idem, Ibidem, p. 319.
} 
Universidade de Ferrara. Nesta cidade italiana viveu até à sua morte, desempenhando prestigiados cargos na Universidade, facto que comprovou a sua elevada competência científica e pedagógica. Sobre este professor e autor, Resina Rodrigues escreveu o seguinte: 15

Inácio Monteiro não foi um criador, nem nunca se apresentou como tal. Foi um homem que procurou compreender e julgar o universo da cultura e para isso se lançou ao estudo, quer das grandes obras do passado, quer dos trabalhos científicos e filosóficos do seu tempo. Foi um professor, e nos seus escritos se sente a paixão de transmitir, de maneira crítica, aquilo que aprendeu.

Inácio Monteiro formou-se intelectualmente num ambiente marcado pela transição e consolidação de novas ideias, onde o valor atribuído às ciências experimentais se revelava progressivamente dominante. No ambiente de infrutíferas polémicas pessoais e institucionais, que caracterizou a vida intelectual portuguesa nos meados do século XVIII, evidenciou-se por uma conduta e por um pensamento tolerante, furtando-se ao confronto inconsequente para o estabelecimento de um ambiente cultural produtivo. Ficou bem célebre a opinião expressa e assumida publicamente no Compendio dos Elementos de Mathematica em defesa do oratoriano Teodoro de Almeida, o qual teria sido muito criticado por ocasião da publicação dos primeiros volumes da Recreasaõ Filozofica. Através da sua obra e da sua prática pedagógica, Inácio Monteiro revelou uma atitude de homem de cultura digna de mérito, evidenciando um apreciável juízo crítico nas apreciações que fazia em relação aos diversos autores que considerava entre os melhores sobre os assuntos abordados. A sua personalidade era caracterizada por uma conduta isenta e independente, não deixando que a sua opinião fosse condicionada pela simples autoridade de quem quer que fosse, por mais sonante que fosse o seu nome.

15 Resina Rodrigues, "Física e Filosofia da Natureza na obra de Inácio Monteiro." História e Desenvolvimento da Ciência em Portugal até ao Séc. XX, Publicações do II Centenário da Academia das Ciências de Lisboa, 1985, vol. I, p. 191-242. 
Foi o próprio Inácio Monteiro a declarar que apenas em matéria de fé religiosa admitia condicionar a expressão das suas opiniões. Foi muito completa a lista de autores modernos e clássicos que utilizou como referência, e sobre os quais apresentou os seus comentários. Demonstrou um vasto conhecimento sobre os mais importantes autores que escreveram sobre temas da ciência. No Compendio dos Elementos de Mathematica, integralmente redigido e impresso no Colégio das Artes, em Coimbra, quando se referia a algum autor, do qual não tinha conhecimento directo, deixava-o devidamente expresso, informando sempre qual foi a fonte a partir da qual teria obtido a referência. Esta situação foi, no entanto, muito rara na obra de Inácio Monteiro. Este facto demonstra que ao longo da sua formação intelectual pôde dispor, em Évora e Coimbra, de bibliotecas de excelente nível, onde não faltavam os autores modernos mais credenciados. Embora reconhecesse e defendesse as vantagens do ensino baseado na experimentação, e admitimos que também o tivesse pretendido introduzir no programa de ensino do Colégio das Artes, na realidade não teve oportunidade de o praticar. Esta situação apenas ter-se-ia verificado por não ter à sua disposição um Gabinete de Física devidamente equipado. O facto de não existirem referências de um ensino baseado em metodologias experimentais nas suas lições não deverá, no entanto, servir como argumento para desvalorizar a sua notável aptidão pedagógica e científica.

Inácio Monteiro não se livrou da humilhação a que foram submetidos todos aqueles que não abandonaram a Companhia de Jesus no período da impetuosa perseguição pombalina aos jesuítas. Foi preso em 1759 quando se encontrava em Santarém, e desterrado para Itália, onde desenvolveu uma actividade pedagógica de reconhecido mérito na Universidade de Ferrara. Mesmo depois da sua ida para aquele país não se livrou das acérrimas e injustificadas críticas que lhe foram movidas por Luís António Verney. As obras que publicou em Itália já faziam, muito provavelmente, parte dos seus projectos quando ainda se encontrava em Portugal. Só a perseguição a que foi sujeito, e a respectiva expulsão verificada em 1759, teriam feito com que muitos dos seus importantes projectos de natureza científico-pedagógica fossem concretizados além 
fronteiras. Viria a falecer em Ferrara no ano de 1812. Até à sua morte acompanhou-o a amargura de nunca mais ter podido regressar a Portugal e de colocar em prática o seu projecto educativo - dar o seu contributo para a formação científica da juventude portuguesa. A carta que publicou em Itália, dedicada à juventude portuguesa, é um documento bem expressivo do seu grande empenho ao ensino. ${ }^{16}$

O dinamismo observado no Colégio das Artes entre 1754 e 1756 não foi, contudo, um acto isolado da actividade pedagógica de carácter científico. Este fervilhar de novas ideias também se estendeu a outras escolas antes da Reforma Pombalina. A primeira metade do século XVIII ficou assinalada pela introdução progressiva e cautelosa das modernas correntes do pensamento científico nos cursos de Filosofia de Inácio Soares, Sebastião de Abreu, João Leitão, Inácio Vieira, e António Vieira, entre outros. ${ }^{17} \mathrm{~A}$ actividade pedagógica observada nalgumas escolas mais prestigiadas denotava alguns indicadores de que o ensino das ciências físico-matemáticas, no período anterior a 1760, não se manteve absolutamente indiferente à nova Ciência emergente desde os tempos de Galileu. Todo este desenvolvimento viria a ter os consequentes reflexos na evolução dos estudos científicos em Portugal. Com efeito, ao longo de todo o século XVII, verificou-se uma significativa actividade de carácter pedagógico e de pesquisa, marcada pela influência de diversos astrónomos e matemáticos portugueses, bem como de alguns outros provenientes dos mais variados países europeus. Não deixa de assumir uma significativa importância o facto de Cristóvão Grienberger, João Paulo Lembo e Cristóvão Clávio terem feito parte de um grupo de quatro matemáticos do Colégio Romano, juntamente com Maelcote, que interpelados pelo Cardeal Belarmino, confirmaram em Março de 1611, em Roma, as mais recentes descobertas astronómicas relativas aos satélites de Júpiter, feitas por Galileu, e publicadas no Sidereus Nuncius em Março de 1610. Refira-se que Cristóvão Grienberger e João Paulo Lembo foram professores no Colégio das Artes e de Santo Antão, e Cristóvão

\footnotetext{
16 Décio R. Martins, ob. cit.

17 Idem, ibidem.
} 
Clávio recebeu a sua formação científica em Coimbra, tendo estudado no Colégio das Artes.

Se, nalguns casos, a influência científica de alguns professores estrangeiros que ensinaram em Coimbra e Lisboa teria sido discreta, noutros, porém, assumiram um grande realce, como seja o caso do Pe. Cristóvão Borri, contemporâneo de Galileu, cujo exemplo serve para demonstrar a actualidade com que em Portugal se acompanhavam os acontecimentos científicos mais importantes na Europa. Os cursos de Filosofia e Astronomia leccionados por João Paulo Lembo, João Delgado, Cristóvão Grienberger, Cristóvão Borri, Inácio Stafford, Henrique Buseu, Baltasar Teles, Soares Lusitano, António Cordeiro, são alguns dos exemplos mais representativos que denotavam uma considerável influência da Filosofia Nova e da Ciência emergente, ensinada ao longo do século XVII, no Colégio das Artes, em Coimbra, no Colégio de Santo Antão, em Lisboa, e na Universidade de Évora. ${ }^{18}$

Durante a primeira metade do século XVIII continuou a verificar-se uma importante influência para o desenvolvimento científico e cultural português daqueles que no estrangeiro tiveram a oportunidade de contactar pessoalmente com os nomes mais representativos da cultura científica europeia. Não menos importante foi a acção daqueles que mantendo-se em Portugal, mas conhecedores da evolução verificada no ensino nas mais prestigiadas escolas europeias, deram um apreciável contributo para um actualizado, embora moderado, acompanhamento das modernas perspectivas pedagógicas praticadas na Europa. Para este desenvolvimento contribuiu uma importante plêiade de intelectuais que do estrangeiro faziam chegar a Portugal referências muito úteis para a introdução de temas científicos actualizados. Considerando o desenvolvimento dos estudos científicos em Portugal na primeira metade do século XVIII, assume especial significado o facto de que Newton morreu no ano de 1727 em Middlesex, tendo sido reconhecido o seu prestígio entre os não pouco portugueses cultos que passaram por Londres nos finais do século XVII e início do século XVIII, dos quais são exemplos

18 Idem, ibidem. 
Fernão Mendes, inventor da famosa água-de-Inglaterra, o diplomata José Faria, eleito sócio da Royal Society em 1682. Também Isaac Sequeira Samuda e A. Galvão de Castelo Branco teriam conhecido Newton pessoalmente, uma vez que ingressaram na Royal Society quando este era presidente desta instituição. Numa sessão plenária da Royal Society, reunida em 10 de Dezembro de 1724 , presidida por Newton, foram lidas as primeiras comunicações das observações astronómicas realizadas em Lisboa, no Colégio de Santo Antão, por João Baptista Carbone e Domingos Capassi. Ainda Newton era vivo, e já em Portugal eram promovidos cursos de Filosofia Experimental, onde se explicavam metodicamente todos os fundamentos, e experiências dos filósofos modernos, com especial destaque para os $f a$ mosos Robert Boyle e Isaac Newton. Um facto que muito terá contribuído para a difusão da Filosofia newtoniana em Portugal foi a ida de Jacob de Castro Sarmento para Inglaterra. Para fugir à Inquisição, em 1721, fixou-se em Londres, mantendo, no entanto, uma importante influência sobre a cultura portuguesa. Jacob de Castro Sarmento foi membro do Real Colégio dos Médicos (1725), e sócio da Royal Society (1730). Na Escócia recebeu o grau de doutor na Universidade de Aberdeen. A sua influência na cultura portuguesa na primeira metade de século XVIII pode ser comprovada pelo facto de ter deixado alguns documentos escritos, como seja a Nova descrição do Globo ou exacta medida dos Impérios, Reinos, Territórios, Estados principais, Condados e Ilhas de todo o Mundo, o qual se encontra na Biblioteca Nacional de Lisboa (ms. 612), e ainda o manuscrito Cronologia Newtoniana Epitomizada, que igualmente se encontra na Biblioteca Nacional de Lisboa (ms. 593). Em 1731 começou a tradução do Novum Organon, de Francis Bacon. Neste mesmo ano enviou para Portugal um pormenorizado plano para a criação de um horto botânico, o qual se encontra na Biblioteca Geral da Universidade de Coimbra. Datado de 1731, existe no Museu de Física da Universidade de Coimbra um microscópio feito por Culpeper, o qual foi oferecido por Jacob de Castro Sarmento à Academia Conimbricense. Este microscópio apresenta na sua base a seguinte inscrição:

JACOB de CASTRO SARMENTO, MEDICUS LUSITANUS, REGALLIS COLEGII, MEDICORUM LONDINENSIUM COLLEGA, REGIAE que SOCIETATIS SOCIUS, 
DONAVIT ACADEMIAE CONIMBRICENCI, in USUM MEDICINAE PROFESSORUM ad obSERVATIONES Botanicas et ANATOMICAS CONFICIENDAS, Anno MDCCXXXI (CULPEPER LONDINENS, invenit et FECIT).

Uma das obras da autoria de Jacob de Castro Sarmento que é tida como uma importante referência da cultura científica portuguesa da primeira metade do século XVIII é a Theorica verdadeira das mares, conforme à Philosofia do incomparável cavalhero Isaac Newton, publicada em Londres no ano de 1737. Igualmente merece referência a Matéria medica physico-historica-mechanica, publicada também em Londres, no ano de 1758.

Outra personalidade de destaque na cultura científica portuguesa nos anos que antecederam a Reforma Pombalina da Universidade foi o oratoriano João Chevalier. Este astrónomo e matemático, de nacionalidade portuguesa, entrou para a Congregação do Oratório de Lisboa em 8.9.1735. Foi professor de Teologia, e dedicou-se ao estudo da História, sobretudo eclesiástica. O seu prestígio levou a que D. João V o encarregasse de formar a Biblioteca de Mafra, tarefa que também executou posteriormente na Casa das Necessidades. Como censor oficial entre 1757 e 1759 viria a rejeitar obras que Barbosa Machado autorizara. ${ }^{19} \mathrm{O}$ Pe. Teodoro de Almeida tinha por ele muita admiração e sujeitava à sua aprovação as obras que publicava. ${ }^{20} \mathrm{O}$ Pe. João Chevalier terá sido um dos mais notáveis astrónomos da Congregação do Oratório, tendo merecido destaque as observações que realizou na Casa das Necessidades entre 1753 e 1757. Ao longo de toda a década de cinquenta a figura de João Chevalier prevaleceu sobre todas as outras pela actividade que desenvolveu em Astronomia enquanto se manteve em Portugal. Tornou-se um correspondente preferencial de De l'Isle, enviando para Paris as observações astronómicas que se fizeram em Portugal, inclusive as realizadas pelos jesuítas. ${ }^{21}$ Foi Chevalier quem deu a conhecer ao astrónomo francês as observações realizadas no Colégio

19 ANTT, Mesa Cens. ms. 403.

${ }^{20}$ A vida do P. Teodoro de Almeida... - Torre do Tombo - ms. da Liv. 2316.

${ }^{21}$ Rómulo de Carvalho, A astronomia em Portugal no século XVIII. Instituto de Cultura e Língua Portuguesa : Ministério da Educação, Março 1985, p. 71. 
de Santo Antão, respeitantes ao eclipse do Sol de 26 de Outubro de 1753. Em 26 de Novembro de 1754 enviou as observações dos eclipses do primeiro satélite de Júpiter efectuadas pelos jesuítas italianos na América do Sul. ${ }^{22}$ Rómulo de Carvalho deu o devido realce ao facto de Chevalier inicialmente ter-se interessado mais pelos assuntos da Física do que de Astronomia, conforme o próprio Chevalier comunicava a De l'Isle numa carta enviada em 25.7.1752.23 Para este interesse muito teria contribuído o facto de existir na Casa das Necessidades uma sala pública para as lições de Física Experimental. Através de Rómulo de Carvalho ficamos a saber que Chevalier observara nitidamente, com o seu telescópio, o anel de Saturno. Sobre a qualidade do instrumento utilizado, De l'Isle comentou ter visto, em Petersburgo, um telescópio construído por James Short em 1741, o qual era semelhante ao utilizado pelo oratoriano, mas que o existente na Casa das Necessidades era de melhor qualidade. Outro material disponível no observatório dos oratorianos era um quarto de círculo, de construção inglesa, de 34 polegadas de raio. Da actividade astronómica de Chevalier contam-se as observações habituais de eclipses da Lua, do Sol, dos satélites de Júpiter, a passagem de Mercúrio sobre o disco solar. Em 9 de Abril de 1759 Chevalier comunicou a Soares de Barros o facto de ter observado no céu no anterior dia 5 um cometa, a baixa latitude, na constelação do Aquário, de cauda pouco comprida mas muito larga e que, pela sua declinação meridional, não seria facilmente observado em Paris. A pedido de Chevalier esta observação foi comunicada a De l'Isle e aos restantes astrónomos de Paris, tendo sido apresentada na Academia das Ciências. ${ }^{24}$ As observações do cometa prolongaram-se por Maio e Junho, até ao dia 22. Tratava-se do cometa Halley, o qual também foi observado por Teodoro de Almeida, a convite de Chevalier, e do qual fez uma pormenorizada descrição. Também em 7 de Janeiro 1760 Chevalier iniciou as observações de outro cometa, facto que comunicou a De l'Isle numa carta enviada a 15 de Janeiro. Nestas observações

\footnotetext{
22 Portefeuille de Delisle, Tomo XVIII, n. os 87 e $87 \mathrm{~b}$.

23 Idem, Tomo XI, n. ${ }^{\circ} 242$.

${ }^{24}$ Idem, Tomo XIV, n. ${ }^{\circ} 95$.
} 
teria sido ajudado por Manuel Domingues. ${ }^{25}$ Também sobre as observações deste cometa Teodoro de Almeida fez algumas considerações na Recreasão Filozofica. Numa carta escrita por Chevalier em 28.12.1762, ${ }^{26}$ dirigida a De l'Isle, informava que Teodoro de Almeida fizera no Porto, já durante o seu desterro, a observação de uma passagem de Vénus sobre o Sol. Para este efeito Teodoro de Almeida teria utilizado um telescópio gregoriano de 2 pés de foco, com um vidro verde e outro defumado, uma pêndula e um quarto de círculo de 2,5 pés de raio. A importância dos trabalhos de Chevalier no domínio da Astronomia levaram a que o seu prestígio chegasse à Academia das Ciências de Paris, de cuja instituição viria a ser sócio correspondente como consequência das diligências feitas por Ribeiro Sanches e do célebre naturalista Buffon, que intercederam junto de De l'Isle para que o astrónomo português fosse proposto ao lugar de correspondente daquela Academia, tendo sido aceite em 12.5.1753. Algumas das comunicações de Chevalier foram também relatadas nas Philosophical Transactions. ${ }^{27}$

Dois nomes que tiveram um importante desempenho e que exerceram uma notável influência no desenvolvimento cultural português no século XVIII, foram Bento de Moura Portugal e João Jacinto de Magalhães. Não se pode deixar de referir o contributo significativo prestado por João Jacinto de Magalhães para a promoção em todo o continente europeu dos instrumentos científicos feitos em Inglaterra. Magalhães, que se radicou em Londres no ano de 1764 , foi um cientista que conquistou um prestígio de grande relevo na Europa. Foi considerado por Weiss, um dos seus mais antigos biógrafos, como um dos homens que mais contribuíram para o progresso da Física na última metade do século XVIII. Este cientista, depois de ter decidido deixar o país, viveu em França a partir de cerca de $1756 / 7$, após o que se fixou em Londres, no ano de 1764. Pronunciando-se sobre o ambiente político que dominava a vida portuguesa, manifestou a sua intenção de não mais viver senão sob um

25 Idem, Tomo XIV, n. 167.

26 Idem, Tomo XV, n. ${ }^{\circ} 48 \mathrm{a}$.

27 Rómulo de Carvalho, Portugal nas Philosophical Transactions nos sécs. XVII e XVIII. Coimbra, 1956. 
governo em que a liberdade pessoal estivesse protegida do despotismo ministerial. Em Inglaterra colaborou e manteve correspondência científica com os cientistas europeus mais notáveis da sua época. O prestígio científico de João Jacinto de Magalhães estendeu-se a todo o continente europeu, desde Lisboa a S. Petersbourg, bem como aos Estados Unidos da América. A sua notoriedade começou a ser reconhecida pela comunidade científica ainda antes do ano de 1772. Pelo facto de ser um conhecedor privilegiado dos melhores fabricantes de instrumentos ingleses, de muito beneficiou, com o seu contributo, o desenvolvimento que viria a ter o Gabinete de Física de Coimbra, bem como o Observatório Astronómico, também criado por ocasião da reforma de $1772 .{ }^{28}$ Magalhães foi membro ou sócio correspondente das seguintes sociedades científicas: Academia das Ciências de Lisboa; Académie Royal des Sciences-Bruxelles; Académie des Sciences-Paris; Academia Imperial de Ciências de S. Petersbourg; Akedemie der Wissenschaften-Berlin; American Philosophical Society-Philadelphia; Hollandsche Maatschappij der Wetenschappen-Haarlen; The Manchester Literary and Phylosophical Society e The Royal Society-London. Em Londres, Magalhães colaborou com a Coroa Espanhola e Portuguesa, enviando para os respectivos países colecções de instrumentos de Astronomia, Física, Náutica, etc., tendo supervisionado a sua construção na capital inglesa. Para a Universidade de Coimbra João Jacinto de Magalhães enviou de Londres um conjunto numeroso de instrumentos de Física e de Astronomia, contendo alguns deles melhoramentos técnicos da sua autoria. O exemplo mais importante é o da máquina de Atwood que ainda hoje faz parte da colecção de instrumentos do Museu de Física da Universidade de Coimbra. Na pêndula do relógio instalado

28 Sobre os aspectos biográficos de João Jacinto de Magalhães vejam-se as seguintes referências:

- João Jacinto de Magalhães, Conference on Physical Sciences in the XVIII Century. Museu de Física da Universidade de Coimbra : Departamento de Física, Coimbra, 1990.

- Manuel Fernandez Thomaz, "Jean-Hyacinthe Magellan, un homme de science portugais dans l'Europe du dix-huitieme siecle". Les Mecanismes du Genie, Europalia 91, Charleroi, Bélgica, 1991.

- Isabel M. C. de Oliveira Malaquias, A obra de João Jacinto de Magalhães no contexto da ciência do séc. XVIII. Dissertação de Doutoramento, Departamento de Física: Universidade de Aveiro, Aveiro, 1994. 
nesta máquina pode ler-se a seguinte inscrição: J.H. Magellan Lusitanus invenit atque fieri Curaviti Londini.

Também não devemos esquecer Bento de Moura Portugal, que na Europa recebeu o cognome de Newton português. O reconhecimento da sua notável competência científica ficou sobejamente expressa ao ter-se afirmado que depois do grande Newton em Inglaterra, só Bento de Moura em Portugal. A sua aprendizagem da Filosofia newtoniana foi feita em contacto directo com alguns dos mais notáveis discípulos de Newton, durante a sua estadia em Inglaterra. O seu regresso a Portugal viria a revelar-se uma opção trágica que o conduziria a um fim de vida dramático. Apesar do seu prestígio, Bento de Moura Portugal viveu os últimos anos da sua vida em condições absolutamente dramáticas e desumanas, vítima do despotismo reinante. O drama e o desespero vivido por Bento de Moura levou-o à tentativa de suicídio, solução extrema para colocar fim às condições humilhantes e degradantes a que foi submetido na prisão. Teodoro de Almeida pretendeu fazer a justiça de não o deixar cair no esquecimento colectivo e expressou de um modo bem vincado a admiração que tinha pela sua pessoa e pelas suas qualidades ímpares de intelectual notável. Este reconhecimento público passou à posteridade quando descreveu o modelo teórico inovador que concebeu para explicar o fenómeno das marés. Nas Cartas Físico-Mathematicas, mais propriamente na carta intitulada Sobre huma máquina para provar a causa das marés, segundo a doutrina do grande Bento de Moura Portugal, ficou bem expressa a homenagem pessoal de Teodoro de Almeida ao seu mérito, bem como uma crítica implícita à conduta despótica e desumana dos responsáveis do seu infortúnio. Referiu-se-lhe deste modo: ${ }^{29}$

Não he sómente... o amor da verdade, e desejo de vos instruir o que me move a escrever esta Carta, mas a honra que devemos à patria, e que nos merecem os Portuguezes; e não devemos deixar escurecer no esquecimento o que lhes póde servir de gloria.

29 Teodoro de Almeida, Cartas Fysico-Mathematicas. Lisboa, MDCCXCIX, tomo III, p. 200-201. 
$\mathrm{O}$ ambiente político e social que se viveu em Portugal nos finais da década de cinquenta e toda a década de sessenta tiveram profundas influências no ensino. Foi uma época assinalada por intervenções mais ou menos fervorosas, a favor e contra as novas perspectivas de pensamento e implantação de novas metodologias de ensino. Por vezes, o choque ideológico foi marcado por intervenções injuriosas e por retaliações pessoais. Por outro lado, o regime político estabelecido foi extremamente duro em relação aos espíritos mais independentes. Todos aqueles que não se vergaram sob a força do despotismo ministerial tiveram o seu futuro comprometido e a sua integridade pessoal ameaçadas. Só a prisão e o êxodo de várias personalidades, algumas forçadas, outras por se recusarem voluntariamente a viver no ambiente político instalado, levou a que, durante toda a década de sessenta, os níveis de ensino e de actividade científica tivessem, efectivamente, atingido a situação verdadeiramente miserável, como eram classificados nos Estatutos Pombalinos da Universidade. Foi durante esta década que se observou a total paralisação das actividades em várias escolas como o Colégio das Artes, Colégio de Santo Antão, Colégio da Casa das Necessidades e Universidade de Évora. Este processo de atrofiamento intelectual e pedagógico foi acompanhado pelas perseguições, prisões e condenações ao exílio, feitas de um modo indiscriminado, atingindo um conjunto numeroso de intelectuais que, posteriormente, no estrangeiro, viriam a confirmar o prestígio científico e pedagógico já anteriormente evidenciados em escolas portuguesas. Alguns destes intelectuais, que se dedicaram às ciências físico-matemáticas, viram o seu mérito reconhecido por várias das mais importantes Academias científicas europeias. Este êxodo generalizado e extermínio de importantes sectores da vida intelectual, intensificados durante toda a década de sessenta, tinha colocado o país num absoluto e lamentável vazio pedagógico e científico. Só esta situação deplorável a que tinha sido reduzida a actividade cultural e científica justificou a necessidade de se recorrer a professores italianos para reactivarem alguns sectores do ensino que, entretanto, tinham sido completamente desmantelados desde finais da década de cinquenta. Foi nestas circunstâncias que vieram para Portugal os professores António Dalla Bella e Domingos Vandelli. 


\section{Os princípios gerais da Reforma Pombalina do ensino das ciências}

físico-matemáticas

No início da década de setenta deu-se a profunda remodelação do sistema educativo português, com grande incidência no ensino das matérias científicas em geral. Nesta época foram proferidas críticas muito incisivas, particularmente em relação ao estado do ensino das ciências físico-matemáticas em Portugal. As análises extremamente negativas foram apresentadas de um modo generalizado e indiscriminado, atingindo todos os sectores de actividade pedagógica e intelectual, com especial relevo dado ao sistema de ensino das escolas jesuítas que vigorou até 1759, e tiveram incidência preferencial nos cursos de Filosofia do Colégio das Artes. Os ideólogos da Reforma Pombalina foram extremamente vigorosos e condenatórios em relação ao anterior sistema de ensino, tendo ficado inequivocamente expressas as suas opiniões nos documentos da Reforma Pombalina. O radicalismo de que os jesuítas foram vítimas tiveram um grande impacto, apesar de se poderem encontrar dados indiciadores de que nalguns cursos se tinha verificado uma significativa influência das modernas perspectivas científicas e pedagógicas que dominavam as principais escolas europeias. A influência da Ciência emergente começou a ser introduzida nos cursos de Filosofia, Matemática e Astronomia, ao longo de todo o século XVII, desde os contemporâneos de Galileu, e no século XVIII, até ao ano de $1760 .{ }^{30}$ Apesar deste carácter inovador, a ideia que prevaleceu, substanciada nos documentos da Reforma Universitária, foi a da absoluta estagnação científica e pedagógica dos jesuítas.

Os desígnios do projecto renovador do ensino das ciências lançado em 1772 foram verdadeiramente meritórios. No entanto, reduzir toda a anterior actividade pedagógica e científica ao nível absolutamente deplorável, como os apresentados em vários documentos da reforma, é no mínimo injusto para um conjunto significativo de personalidades que se empenharam na contínua actualização dos temas científicos contemplados no ensino ao longo de todo o século XVII e no século XVIII

30 Décio R. Martins, ob. cit. 
até ao ano de 1760. A nova Filosofia e a Ciência emergente do início do século XVII começaram a encontrar nas principais escolas portuguesas simpatizantes fervorosos, quer entre professores estrangeiros, quer nacionais. Os dogmas peripatéticos começaram a ser colocados em causa nas lições de alguns professores do Colégio das Artes, Colégio de Santo Antão e Universidade de Évora, ainda entre os contemporâneos de Galileu que ensinavam Filosofia e Astronomia naquelas escolas. Na verdade, o ensino das ciências físico-matemáticas em Portugal não morreu com Pedro Nunes, para ressuscitar com os ventos renovadores de 1772 . Alguns foram os nomes de estrangeiros que deram um importante contributo para o desenvolvimento do ensino das matérias científicas, os quais eram provenientes de vários pontos da Europa e de prestigiadas instituições científicas onde tinham conquistado um reconhecido mérito. Mas não foram apenas estrangeiros aqueles que têm os seus nomes ligados à introdução e desenvolvimento nas principais escolas portuguesas do ensino das novas concepções científicas e filosóficas ao longo dos séculos XVII e XVIII. ${ }^{31}$

Apesar destes indicadores, os Estatutos da Universidade de Coimbra de 1772 referiam-se de uma forma explícita aos aspectos alegadamente perniciosos do sistema de ensino vigente, dando especial ênfase ao pretenso estado deplorável do ensino da Filosofia em geral e das ciências físico-matemáticas em particular. Neste documento, depois de serem enunciados os objectivos gerais relativos à organização da nova Faculdade de Filosofia, afirmava-se o seguinte: 32

E porque a miseravel Faculdade chamada até agora Das Artes, e incorporada na Universidade, tão longe esteve de satisfazer a estes importantes objectos, que muito pelo contrário foi a origem, e raiz venenosa, donde nasceo a escura, pueril, e sofistica loquacidade, que invadio, e corrompeo todos os Ramos do Ensino público: Hei por bem,

31 Idem, ibidem.

32 Estatutos da Universidade de Coimbra, Livro III. Na Regia Officina Typografica. Anno MDCCLXXII, p. 223-224. 
e Sou servido abolir a dita Faculdade, como systema incorrigivel, e indigno de Refórma; substituindo no lugar della huma nova Faculdade, que mais se não chamará De Artes, mas sim de Filosofia; regulada, e dirigida efficazmente a produzir os bons effeitos, que della resultam, quando não se emprega em fallar, mas em saber.

Considerando tambem, que as Sciencias Filosoficas, além de se acharem depravadas, e corrompidas na sobredita Faculdade das Artes, estavam degradadas do justo lugar, que merecem; fazendo-se dellas huma Faculdade inferior, menor, ao mesmo tempo, que se tinha collocado a Medicina entre as Faculdades maiores, quando ella não he outra cousa mais, do que huma Parte da mesma Filosofia: E Attendendo a que esta differença não póde ter outros effeitos, que não sejam os de arruinar os Estudos Filosoficos, e de desanimar a applicação dos que nelles podiam empregar-se com utilidade pública do Estado: Hei por bem outro sim ordenar, e estabelecer, que a Faculdade de Filosofia seja daqui em diante reputada, e havida por huma Classe maior do Ensino público, em tudo igual ás outras Faculdades; procurando da sua parte produzir no seu gremio Filosofos consummados; dignos das luzes deste Seculo; e conformes ao espirito dos presentes Estatutos, que Tenho disposto para Regulamento della.

Um argumento frequentemente utilizado para se fundamentar a opinião de que em Portugal, anteriormente à Reforma Pombalina dos estudos, se vivia um ambiente de profunda ignorância e estagnação científico-cultural foi o facto das obras de Galileu, Gassendi, Descartes, Newton, entre outros autores, se encontrarem oficialmente interditas ao ensino no Colégio das Artes. Com efeito, o Edital do Reitor do Colégio das Artes de Coimbra de 7 de Maio de 1746, através do qual se tornava pública esta proibição, que constituiu um facto histórico de relevo, deixava transparecer um atraso significativo relativamente ao desenvolvimento científico observado na Europa, o qual teve as suas raízes mais profundas no século XVII. Outro argumento utilizado residia nas deliberações contidas nos antigos Estatutos da Universidade, relativas ao curso de Filosofia ministrado no Colégio das Artes, embora por várias vezes os jesuítas 
que ensinavam nesta escola tivessem tentado introduzir alterações que os libertassem da imposição oficial de seguirem as ideias peripatéticas. Por outro lado, a inexistência de uma prática de ensino fundamentado nos métodos experimentais teria contribuído para o precário desenvolvimento tecnológico do país. Perante este panorama, tornava-se urgente que se tomassem as medidas adequadas para que Portugal não ficasse insensível ao desenvolvimento científico e tecnológico europeu.

Perante críticas tão enérgicas impunha-se uma transformação radical em todo o sistema educativo. A acção de D. Francisco de Lemos foi decisiva para a mudança julgada necessária. Na Relação Geral do Estado da Universidade de Coimbra deixou expressa de uma forma indubitável a sua opinião sobre a necessidade imperiosa da existência nos estudos universitários de um curso onde a Filosofia fosse abordada numa dimensão verdadeiramente moderna. A Universidade deveria acompanhar o ritmo evolutivo da Ciência que se verificava nos mais importantes centros universitários europeus, e ser ela própria um importante factor para o desenvolvimento da cultura e do conhecimento científico. Defendia uma perspectiva de evolução dinâmica para o novo sistema de ensino que se desejava implantar ao afirmar que:

...todas as Sciencias se aperfeiçoão cada vez mais, e se enriquecem com descobrimentos novos, que logo devem incorporar-se nos respectivos Cursos das Lições publicas; E por outra parte; que tem mostrado a experiência, que as Universidades nem tem infelizmente promovido estes conhecimentos, nem tem recebido com a promptidão os descobrimentos, que de novo se tem feito em todas estas Sciencias, porque sendo destinadas ao ensino publico se julgam limitadas a um Curso de Lições positivas, e só trabalham, e se ocupam em conservar, e defender as que huma vez começaram a ensinar com grande prejuizo do Bem comum, e do adiantamento das letras.

As palavras de D. Francisco de Lemos testemunham um grande ideal pedagógico bem característico do século das luzes. A Reforma Universitária deveria dar origem a uma instituição de ensino dinâmica, actualizada e 
geradora de novos saberes. Pronunciando-se sobre a Filosofia Escolástica, que até então se considerava ter dominado em absoluto o sistema educativo português, e perspectivando uma solução que conduzisse o ensino das ciências a uma situação que se pretendia equiparável à das melhores escolas europeias, afirmou o seguinte:

... esta Filosofia, que com dicredito da razão por tantos seculos ocupou este nome só servia de deslocar o Entendimento dos homens, que corrompem os estudos de todas as mais Faculdades, e de uma ruina geral das Artes; as quais não podiam adiantar-se, e nem promover-se, por meio de uma Siencia verbal, toda destituida de conhecimentos fizicos, e verdades certas na Natureza; Pareceu à Junta Literaria, que devia ser abolida não só da Universidade, mas também de todas as Escolas publicas, e particulares, seculares e regulares d'estes Reynos, e Senhorios.

Para os promotores da reforma universitária, uma acção eficaz, que retirasse o ensino das ciências físico-matemáticas da situação considerada extremamente degrada e obsoleta em que se encontrava, só poderia ser concretizada através da eliminação radical das anteriores escolas e da criação de novos estabelecimentos de ensino. Para o efeito, foi considerado fundamental que se rompesse definitivamente e radicalmente com tudo o que fosse considerado a causa do alegado insustentável e incorrigível atraso científico. As medidas consideradas mais importantes a pôr em prática deveriam conduzir à organização de novas unidades de ensino que estivessem em conformidade com as novas correntes pedagógicas que, ao longo do século XVIII, progressivamente se iam implantando na Europa. Estes novos estabelecimentos deveriam alargar os horizontes da cultura científica portuguesa, retirando-a da situação considerada deplorável em que se encontrava, e aproxima-la dos padrões dos países mais avançados da Europa. A nova Universidade deveria assumir uma posição de vanguarda científica e pedagógica, desempenhando um papel interveniente e com profundos reflexos na vida social, científica e tecnológica. Na apreciação que fez sobre o estado da Universidade de Coimbra, o Reitor Reformador deixou bem expressa a sua opinião sobre a influência que a Universidade deveria 
ter no processo de desenvolvimento do país. Segundo ele, a organização do estudo das ciências naturais deveria ter como consequência desejável um melhor conhecimento das riquezas naturais, trazendo para a indústria novos recursos materiais. A concretização destes objectivos deveria constituir a base absolutamente indispensável para o desenvolvimento do comércio. Os desígnios do novo projecto educativo deveriam fixar-se na consecução de um objectivo considerado prioritário e fundamental - que o ensino experimental das ciências da natureza tivesse como resultado primordial o desenvolvimento de novas artes, novas manufacturas, novas fábricas, e o aperfeiçoamento das existentes.

As críticas deixadas expressas nos documentos pombalinos da reforma universitária foram extremamente difamatórias de todos aqueles que em Portugal se dedicaram ao ensino e às ciências antes de 1772. Estas críticas foram particularmente contundentes em relação aos jesuítas do Colégio das Artes. Como proposta alternativa, que enquadrasse o sistema educativo português nos padrões de vanguarda do século do iluminismo, delineou-se o projecto de reforma dos estudos universitários, com incidência particular na promoção do ensino científico. Os objectivos estabelecidos no projecto de reforma do ensino das ciências físico-matemáticas na Universidade foram planeados no contexto de uma perspectiva moderna. Os princípios orientadores do ensino que se pretendia colocar em prática pressupunham uma nova dinâmica pedagógica e preconizavam metodologias de ensino alegadamente nunca antes vistas nas escolas portuguesas.

Pela importância que assumia o ensino da Filosofia tornava-se imperioso que um grande investimento humano e financeiro fosse feito. Na opinião de D. Francisco de Lemos não havia Príncipe que não mostrasse um grande zelo e desvelo em honrar a Matemática e as Ciências Naturais, animando com a sua atenção os génios. Deveriam ser seguidos os exemplos dos Estados que procuravam recrutar para os seus serviços aqueles que se mostrassem capazes de contribuir para o desenvolvimento científico do país. Por esta razão os italianos Domingos Vandelli e António Dalla Bella foram contratados para professores da Faculdade de Filosofia.

D. Francisco de Lemos desejava tornar o século XVIII numa época memorável à posteridade através da obra a desenvolver na Universidade 
de Coimbra. De facto, as reformas do ensino realizadas na Academia de Coimbra tornaram-se memoráveis, e o nome do Bispo Reformador viria a ser imortalizado pelo mais elevado empenho que dedicou na sua realização. Em sua opinião, não só à Universidade estaria guardado o dever de tão elevada tarefa. Para o Reitor Reformador também à Academia das Ciências estava destinada uma acção preponderante. Na sua análise deixou expressa a seguinte interrogação:

A quem deve Inglaterra e França a sua opulencia, e o florente estado das Artes da Paz, e da Guerra, se não à Sociedade Real de Londres, e a Academia Real das Sciencias?

Tal como Paris e Londres também Lisboa deveria ver a sua Academia das Ciências contribuir para o progresso científico do país. D. Francisco de Lemos referia-se à importância de uma Academia de Ciências para o desenvolvimento científico e enriquecimento intelectual citando o exemplo da Academia de S. Petersburgo da seguinte forma:

Quazi em nossos dias ainda estava ao Norte da Europa hum vasto paiz submergido nos horrores da barbaridade, a Russia: Quiz Pedro o Grande introduzir as instituições Politicas, Civis, e Militares, que em pessoa tinha observado nas regiões do Meio Dia. Que medidas tomou? Levantou-se a Academia de Petresbourg, e tudo foi feito.

O plano de reorganização do ensino das ciências na Universidade de Coimbra assentava nos pressupostos de uma total e radical ruptura com o passado. No entanto, quis o destino que fosse um ex-jesuíta quem mais se destacou na organização dos estudos científicos nas recém criadas Faculdades de Filosofia e de Mathematica. Ao contrário das opiniões extremamente contundentes expressas nos Estatutos de 1772, este facto deixava antever que nem tudo, mesmo entre os jesuítas, correspondia ao lúgubre panorama apresentado de um modo indiscriminado em relação ao nível científico e pedagógico daqueles que se dedicavam ao ensino das matérias científicas no período que antecedeu a Reforma 
da Universidade. Na realidade, foi o ex-jesuíta Monteiro da Rocha, que tinha abandonado a Companhia de Jesus durante a intensa e impetuosa perseguição movida a todos os elementos que se mantiveram fiéis a esta instituição, o principal mentor do programa de estudos nas novas Faculdades de Filosofia e de Mathematica. A origem da sua qualificação científica e pedagógica, obtida em escolas tão intensamente combatidas pelos mais intransigentes críticos e oponentes do sistema educativo dos jesuítas, não impediu que se afirmasse como um dos mais notáveis e empenhados ideólogos e colaboradores na definição e concretização do plano de estudos das Faculdades de Filosofia e de Matbematica do projecto pombalino da reforma universitária. Foi por intervenção do bispo de Coimbra, D. Francisco de Lemos, que o Marquês de Pombal teve notícia do raro merecimento de José Monteiro da Rocha, e, tendo-o chamado a Lisboa, encarregou-o da organização dos novos Estatutos da Universidade na parte das Ciências Naturais. Por decreto de 11 de Setembro de 1772 foi nomeado professor da Faculdade de Mathematica para a cadeira de Sciencias Physico-Mathematicas. Por decreto de 4 de Junho de 1783 foi nomeado lente de Astronomia, e depois jubilado nela por carta régia de 4 de Abril de 1795, e por outra carta régia de 15 do mesmo mês foi nomeado, como decano e lente de prima, director perpétuo da Faculdade e do Observatório. Por carta régia de 2 de Junho de 1801 foi agraciado com a comenda de Portalegre da Ordem de Cristo, tendo já obtido precedentemente a cadeira do cónego magistral de Leiria. Começou a exercer o cargo de vice-reitor da Universidade em Outubro de 1783, por nomeação do Principal Castro, então reitor da Universidade, e serviu esse cargo até 23 de Maio de 1801, em que foi chamado à corte para mestre de sua alteza o Príncipe D. Pedro e mais infantes, cargo que desempenhou até à saída da família real para o Brasil. Por carta régia de 18 de Agosto de 1804 foram-lhe concedidas todas as honras e preeminências de vice-reitor. Tendo comprado uma quinta no sítio de S. José de Riba-Mar, próximo a Lisboa, aí passou os seus últimos anos, falecendo em 11 de Dezembro de 1819, depois de ter completado oitenta e cinco anos de idade.

Com o plano de estudos delineado por Monteiro da Rocha pretendia-se que o ambicioso projecto educativo de 1772 se concretizasse através 
de uma metodologia experimental, considerada inovadora no ensino das ciências físico-matemáticas em Portugal. O estudo experimental era complementado por desenvolvimentos teóricos feitos em disciplinas devidamente programadas para esse fim. É inegável que a Reforma Pombalina da Universidade trouxe uma nova dinâmica pedagógica e uma maior profundidade científica. As áreas de ensino tornaram-se mais abrangentes. As recém criadas Faculdades de Filosofia e de Mathematica foram concebidas como unidades de ensino das ciências que apresentavam características de modernidade e de complementaridade pedagógica. Nestas duas Faculdades os temas científicos eram apresentados com considerável profundidade teórica e muito bom suporte experimental, particularmente nos assuntos de várias áreas relacionadas com a Física. Preconizava-se que as metodologias de ensino das ciências físico-matemáticas se fundamentassem em estratégias comparáveis às mais inovadoras que eram praticadas nas melhores escolas europeias. Duas das mais importantes realizações deste novo projecto educativo foram as criações do Gabinete de Fysica Experimental e do Laboratório Chymico.

\section{O Gabinete de Física Experimental}

O ensino da Filosofia Experimental foi considerado pelos mais influentes ideólogos da Reforma do ensino como uma das necessidades mais urgentes da instrução pública em Portugal. Com a Reforma da Universidade de Coimbra em 1772, o Gabinete de Física Experimental surgiu integrado na Faculdade de Filosofia. A primeira colecção de instrumentos que o enriqueceu esteve intimamente ligada à extinção do estudo da Matemática e da Física no Colégio dos Nobres em Lisboa. $\mathrm{Na}$ sua origem podemos encontrar pressupostos pedagógicos que ainda hoje mantêm a sua validade. Nos Estatutos da Universidade, de 1772, pode ler-se: ${ }^{33}$

33 Idem. p. 267. 
Para que as Lições de Fysica, que mando dar no Curso Filosofico da Universidade, se façam com aproveitamento necessário dos estudantes; os quaes não sómente devem ver executar as Experiencias, com que se demonstram as verdades até o presente, conhecidas na mesma Fysica; mas também adquirir o habito de as fazer com sagacidade, e destreza, que se requer nos Exploradores da Natureza; haverá também na Universidade huma Collecção das Máquinas, Aparelhos, e Instrumentos necessários para o dito fim.

Um dos objectivos para a criação do Gabinete de Física foi que se ministrasse o ensino da Física Experimental, através do qual se mostrasse o objecto desta ciência, a sua origem, progressos e as revoluções científicas que ao longo da história se observaram. Por outro lado, o desenvolvimento da competência individual no que respeita ao domínio do método experimental não foi esquecido. A arte de fazer as experiências, tendo-se a noção de como as repetir, combinar, distinguir os factos acessórios dos principais, bem como o controle de variáveis de que um sistema físico depende, constituíram uma das metas a atingir com a sua inclusão no plano de estudos do Curso Filosofico. Destes objectivos deveria estar consciente o lente da cadeira. O objectivo principal das experiências em que se deveria empenhar o professor era o de descobrir as leis gerais que regem a natureza nas suas operações. Não apenas o carácter qualitativo deveria estar contemplado no ensino ministrado. Nos Estatutos Pombalinos da Universidade determinava-se que: 34

Não se ocupará com tudo em mostrar por Experiencias os resultados da Theoria e do Cálculo; os quaes, supposta a firmeza dos Principios, são mais exactos do que o resultado das Experiencias feitas em ponto pequeno, e complicadas com muitas circumstancias parciaes, que influem no effeito: Por isso sómente se fazem com utilidade, quando se dirigem unicamente a comparar o resultado mecanico com o calculado; para se conhecer pela differença a resistencia das máquinas, a fricção, e outras circumstancias, que influem no jogo dellas.

${ }^{34}$ Idem. p. 246. 
Através de experiências bem feitas e discutidas, o professor deveria explicar as verdades que até então se haviam descoberto acerca das propriedades gerais dos corpos, tais como a extensão, a divisibilidade, a figura, a porosidade, a compressibilidade, a mobilidade, a elasticidade, etc. O estudo das leis de equilíbrio, do movimento simples e composto, dos fenómenos da gravidade e da aceleração dos graves, estavam no âmbito de uma Física Geral. O programa da disciplina de Física Experimental limitava-se aos princípios fundamentais e aplicações imediatas que pela experiência e pela Geometria elementar se podiam entender. Todo o tratamento teórico mais elaborado seria deixado para ser convenientemente tratado no Curso Mathematico.

Por ocasião da fundação do Gabinete de Física a perspectiva orientadora do ensino da Física Experimental pautava-se pela importância dada à realização e observação de experiências reais, através das quais os fenómenos físicos eram postos em contacto directo com os alunos. Pretendia-se com tal metodologia que o estudante de Física não se limitasse a ver executar as experiências, mas que também fossem habituados na resolução de problemas concretos de que o trabalho experimental se mostrava manifestamente rico. Os estudantes não poderiam ser meros espectadores. Para a concretização de um ensino baseado nestes pressupostos foram reunidas na Casa das Máquinas algumas centenas de instrumentos. Neste local, e sempre que se afigurasse aconselhável, o lente de Física procurava desenvolver uma metodologia de ensino na qual as experiências científicas fossem realizadas pelos próprios estudantes. Desta forma, o hábito da observação, a sagacidade, a destreza e o espírito crítico eram algumas das componentes contempladas na formação dos futuros Exploradores da Natureza.

D. Francisco de Lemos empenhou-se notoriamente na concretização do projecto de instalação do Gabinete de Física Experimental. Foi numerosa a correspondência que trocou com o governo dando informações sobre a evolução de todo o processo de instalação do Gabinete, bem como solicitando acções concretas para que os objectivos não fossem comprometidos. Este facto pode ser comprovado através dos Documentos da Reforma Pombalina, publicados por Lopes de Almeida, em 1937. 
O estudo de Física Experimental era precedido do conhecimento fundamental da História da Natureza. Considerava-se importante que o estudante fosse previamente colocado perante os factos que a simples observação permitia mostrar aos olhos do observador. Também uma preparação prévia em Geometria Elementar e em Matemática Geral se afigurava indispensável para o desenvolvimento nos estudos de Física.

A cadeira de Fysica Experimental correspondia à cadeira do $3^{\circ}$ ano do plano de estudos do Curso Philosophico, assim constituído:

$1^{\circ}$ ano - Philosophia Racional e Moral

$2^{\circ}$ ano - História Natural; Geometria

$3^{\circ}$ ano - Fysica Experimental; Cálculo

$4^{\circ}$ ano - Chimica Theorica e pratica; Phoronomia

O lente da cadeira de Fysica Experimental deveria principiar as suas lições mostrando o objecto da Física, as suas origens e progressos, bem como as revoluções científicas que até então constituíam a sua história. O estudante deveria ter conhecimento de que as revoluções científicas se haviam dado ${ }^{35}$..

...gyrando de hypoteses em hypoteses, e de Systemas em Systemas, até se reduzir à Estrada Real da Experiencia, pela qual sòmente se podem fazer os convenientes progressos.

Esta afirmação encontrada nos Estatutos Pombalinos deixava bem vincada a preocupação de se apresentar o conhecimento científico numa perspectiva evolutiva, na qual os modelos aceites apenas seriam válidos enquanto conseguiam ajustar-se ao real.

No processo de formação o estudante de Física deveria ser advertido para o facto de que as causas dos fenómenos da Natureza estariam fora do alcance das simples especulações do entendimento humano. Toda a Ciência Física deveria reduzir-se primeiramente à colecção de factos averiguados pela experiência, e depois disso à sua combinação e generalização até se chegar à descoberta de um facto primordial que fizesse

35 Idem. p. 24. 
as vezes de causas a respeito das nossas luzes. Através do facto primordial explicar-se-iam sinteticamente os factos particulares. Quando não fosse possível encontrar um efeito geral, em relação a uma matéria específica, o estudante deveria ser habituado à simples colecção das verdades decisivamente provadas por via de facto, abstendo-se de imaginar hipóteses e de fabricar sistemas gratuitos. Estes teriam para a Filosofia o mesmo papel que a fábula na História. A Física deveria continuar as suas pesquisas até encontrar os princípios susceptíveis de aplicação da Geometria e do Cálculo. Seria sempre seu objectivo procurar o como e o porquê dos fenómenos naturais. Este pressuposto conduzia à necessidade de uma formação teórica complementar, a qual os estudantes deveriam obter em cadeiras específicas leccionadas na Faculdade de Mathematica. A Matemática incumbia-se de averiguar o quanto dos fenómenos da Natureza que eram o objecto fundamental das ciências físico-matemáticas. Os ramos da Física para os quais não se revelasse possível descobrir os princípios gerais, através dos quais se explicassem completa e perfeitamente a razão dos fenómenos e os respectivos cálculos, limitar-se-iam na colecção dos factos e no seu ordenamento. A explicação de uns fenómenos pelos outros, e a busca da sua mútua dependência consistia, por vezes, uma metodologia de ensino. O ensino da Física Experimental desenvolvia-se com base na recolha e agrupamento das verdades que decisivamente eram provadas pelas experiências, as quais deveriam ser feitas e discutidas num gabinete experimental devidamente apetrechado. Para a garantia da eficácia dos métodos de ensino, baseados na experimentação, o professor deveria evitar as operações de máquinas complicadas com aparelhos supérfluos. Estes, para além da maior despesa que representavam, conduziam muitas vezes ao erro. Segundo o ponto de vista apresentado nos Estatutos Pombalinos era manifesto que ${ }^{36} \ldots$

... quantos mais são os meios, que se empregam, tanto he mais difícil distinguir a qual deles se deve atribuir o effeito, que resulta das Operações.

36 Idem. p. 248. 
Sobre a importância que então era dado ao ensino da Física Experimental, refira-se o facto deste ensino ser considerado fundamental para a preparação científica dos futuros estudantes de Medicina, conforme a letra dos Estatutos da Universidade de 1772. No capítulo relativo aos Estudos preparatórios para o Curso Medico afirmava-se que os estudantes que o pretendiam frequentar, deveriam $\operatorname{ser}^{37} \ldots$

... previamente instruídos nos Estudos Filosoficos e Mathematicos, necessarios para entrar com sólidos principios no Estudo da Medicina, que he huma Fysica particular do corpo humano cujo mecanismo não he possivel entender-se sem precederem os ditos Estudos.

Para o efeito, os estudantes de Medicina deveriam ouvir, no primeiro ano do curso preparatório, as Lições de Geometria no Curso Geral de Matemática, e de História Natural no Curso Geral de Filosofia; no segundo ano frequentariam as lições de Cálculo no Curso Geral de Matemática, e de Fysica Experimental no Curso Geral Filosofia; no terceiro ano ouviriam as lições de Phoronomia no Curso Geral de Matemática, e de Chimica Theorica e Pratica no Geral de Filosofia. Os estatutos Pombalinos estabeleciam que os estudantes médicos não ficariam dispensados deste triénio de estudos de Matemática e Física38,

...a titulo de qualquer tempo, que em outra parte tenham efectuado o Curso ordinario de Filosofia; por este não conter os conhecimentos necessarios da Sciencia Natural de hum modo completo, como são indispensaveis a quem pertende fazer progressos na Medicina.

A importância da formação científica nesta área considerada fundamental não se resumia apenas ao conhecimento dos factos estudados em Física, mas também ao seu método específico que deveria servir como referência para todas as outras ciências experimentais. Os Estatutos

\footnotetext{
37 Idem. p. 9.

38 Idem. p. 10.
} 
Pombalinos referiam-se às características que deveriam ter as disciplinas do Curso Médico nos seguintes termos ${ }^{39}$ :

Todas as referidas Disciplinas se ensinarão, como Tenho disposto, sem adhesão a Systema algum; mas imitando se possível for o methodo dos Geometras tanto Synthetico, como Analytico; conforme a natureza das materias o permitir; e olhando sempre para os principios demonstrados na Fysica, Mecanica, e Hydraulica.

\section{O programa da cadeira de Fysica Experimental.}

O Gabinete de Física foi equipado com cerca de seis centenas de machinas. Cada um dos instrumentos didácticos, concebidos para a prática do ensino da Física baseado fundamentalmente na experimentação, tinha uma concepção específica que o adequava a um dos capítulos do programa minucioso e previamente estabelecido. Os vários capítulos em que se encontrava dividido o programa da cadeira de Física Experimental eram os seguintes: propriedades gerais dos corpos; mecânica dos fluidos; propriedades do ar; propriedades da água e do fogo; propriedades da luz; propriedades dos corpos magnéticos; propriedades eléctricas da matéria.

Cada um destes capítulos da Física era objecto de um tratamento desenvolvido, sendo considerados os seguintes aspectos:

\section{I - Propriedades Gerais dos Corpos.}

- Neste capítulo os estudantes eram postos em contacto com os fenómenos físicos que atestavam a extensão, a divisibilidade, a figura, a porosidade, a compressibilidade, a mobilidade, a elasticidade, para além de outras propriedades da matéria. O estudo das leis do equilíbrio e do movimento simples e composto desenrolava-se através da explicação dos fenómenos da gravidade, da aceleração dos graves bem como de outros fenómenos relativos à Física geral. Através do estudo do movimento

39 Idem. p. 21. 
dos corpos mostravam-se os princípios fundamentais e as aplicações imediatas que pela experiência e pela Geometria Elementar se podiam entender. Todo o tratamento matemático mais elaborado seria deixado para o Curso Mathematico.

\section{II - Mecânica dos fluidos.}

- O estudo da Mecânica dos fluidos era contemplado com experiências que se destinavam à determinação experimental da gravidade específica e relativa dos Corpos. Por outro lado, realizavam-se experiências para a observação da subida dos líquidos pelos tubos capilares, bem como o uso dos barómetros.

\section{III - Propriedades do Ar.}

- Para o estudo das Propriedades do Ar realizavam-se experiências através das quais se evidenciava o seu peso absoluto, densidade, dilatação e elatério. Também os fenómenos relativos à acústica estavam contemplados no estudo das propriedades do ar. Para isso, o Gabinete de Física dispunha, entre outros, de alguns instrumentos destinados a ajudar $e$ aperfeiçoar o sentido de ouvir.

\section{IV - Propriedades da Água e do Fogo.}

- O efeito do calórico no que respeita às mudanças de estado da água, tal como o da dilatação dos corpos sob a acção do fogo dominava os estudos experimentais neste capítulo. Para a realização destas experiências, algumas delas com magníficos efeitos de espectaculosidade, foram concebidos vários instrumentos, alguns dos quais revestindo-se de extrema importância nas Artes necessárias à Sociedade humana.

\section{V - Propriedades da Luz.}

- O estudo das propriedades da luz fazia-se com recurso a magníficos instrumentos cuja concepção artística provocava o encanto de quem os observava. A observação de efeitos magníficos obtidos através da reflexão e refracção da luz, como sejam as anamorfoses, câmaras ópticas e teatro óptico, a lanterna mágica, até à utilização de excelentes exemplares de 
microscópios e telescópios importados de Inglaterra permitia aos estudantes uma aprendizagem onde a componente lúdica se revelava eficaz.

\section{VI - Propriedades dos Corpos Magnéticos.}

- As manifestações do geomagnetismo, o conhecimento da declinação e inclinação magnética, o magnetismo artificial e natural eram objecto de estudo, tendo-se a preocupação da não dissimulação dos factos que não eram do domínio do conhecimento científico da época. Procurava-se, no entanto, uma explicação Física que fosse convenientemente justificativa dos fenómenos evidenciados pela experiência.

\section{VII - Propriedades Eléctricas da Matéria.}

- Tal como o magnetismo, a electricidade, tanto natural como artificial, apresentava-se como outro enigma da Física. O professor, no entanto, não deixava de mostrar aos seus alunos uma numerosa série de experiências, algumas delas caracterizadas por surpreendentes efeitos luminosos, como sejam as que eram realizadas com os tubos fulminantes e os ovos eléctricos. No desenrolar deste capítulo da Física procuravam estabelecer-se as analogias possíveis no que respeitava à explicação dos fenómenos naturais, tal como o terramoto, o trovão e os raios eléctricos.

\section{A origem dos instrumentos científicos e didácticos}

Para satisfazer aos princípios metodológicos que levaram à inclusão da cadeira de Fysica Experimental no plano de estudos do Curso Filosofico, e para o bom cumprimento da acentuada componente experimental que a caracterizava, havia que equipar convenientemente o Gabinete de Física criado em Coimbra. Neste aspecto o projecto foi ambicioso. O material didáctico com que o Gabinete foi equipado tinha sido inicialmente fabricado, ou adquirido para uso no Colégio Real dos Nobres de Lisboa, e daí transferido para Coimbra em 1773. O seu fabrico ou aquisição deve ter decorrido cerca do ano de 1766, ano em que começaram as actividades docentes no Colégio dos Nobres. Para ensinar Física neste Colégio, havia 
sido contratado António Dalla Bella, que veio da cidade italiana de Pádua. Para proceder ao trabalho de fabrico de algumas machinas, contou-se com a competência de Joaquim José dos Reis, que na época era mestre de obras no edifício do Colégio dos Nobres. São da sua responsabilidade os trabalhos magníficos em madeira, através dos quais se conseguiram verdadeiras obras de arte destinadas ao ensino da Física. As peças de metal foram elaboradas na Real Fábrica, sob a orientação do genovês Pedro Schiappa Pietra, na época radicado em Portugal. Devido à falta de técnicos especializados nalguns domínios, importaram-se de Inglaterra vários instrumentos. Estes foram encomendados a famosos fabricantes cuja reputação internacional era indiscutível. Para este efeito contou-se com a preciosa colaboração de João Jacinto de Magalhães, então radicado em Londres.

Com a criação do Gabinete de Física Experimental da Universidade de Coimbra, o ensino desta ciência aproximava-se da prática de metodologias pedagógicas já com algumas tradições nas principais escolas europeias. De facto, o desenvolvimento do ensino universitário da Física Experimental constituiu um dos mais importantes aspectos da renovação pedagógica ocorrido em Inglaterra no início do século XVIII. O físico e astrónomo escocês John Keill iniciou em Oxford, no ano de 1700, uma nova metodologia de ensino da Física, tornando-se o primeiro a realizar experiências durante as suas lições. Também Hauksbee, ainda no princípio do século, realizou em público algumas demonstrações de Electricidade, Hidrostática e Pneumática. Estes terão sido os primeiros passos para a instalação sistemática de Gabinetes de Física Experimental destinados ao ensino.

Um dos aspectos mais característicos do desenvolvimento das ciências experimentais foi o do aparecimento no século XVIII de grandes oficinas onde a produção de instrumentos se encontrava alargada a todos os domínios da aparelhagem científica. Algumas destas oficinas que surgiram em Londres conseguiram uma forte implantação não só na Europa, mas também noutros continentes. Dos fabricantes londrinos que viriam a receber encomendas de instrumentos científicos e didácticos para o Gabinete de Física Experimental do Colégio dos Nobres e que posteriormente viriam a pertencer ao Gabinete de Física da Universidade de Coimbra, aos quais se juntaram novas encomendas, devemos salientar os nomes de Francis 
Watkins, George Adams, Edward Nairne, Edmund Culpeper, Dollond, James Champneys, Benjamin Martin, Pyefinch. A oficina de George Adams foi fundada em 1735. Acima de tudo, Adams era um especialista em Mecânica e dedicou-se à construção de aparelhos de demonstração para Gabinetes de Física. A par de instrumentos de desenho e microscópios, largamente representados na sua colecção, tinham especial realce uma completa gama de instrumentos de demonstração das leis da Física. Após a sua morte, em 1773, George Adams foi substituído na orientação da oficina pelo seu filho, o qual viria a falecer em 1795, do que resultou o início de um período de dificuldades para a empresa, acabando esta por ser extinta em 1830. Benjamin Martin tornara-se famoso no comércio de instrumentos com um grande número de modelos de microscópios e foi um dos primeiros a adaptar aos seus aparelhos aperfeiçoamentos mecânicos, conferindo-lhes uma qualidade especial. Para além de microscópios, este fabricante notabilizou-se na construção de octantes e telescópios de reflexão. No fabrico de planetários instalava sistemas de movimento de relojoaria de sua invenção. Devido à sua reputação de excelente construtor, conseguiu assegurar uma larga difusão de instrumentos, não só em Inglaterra mas por todo o continente europeu. Descendente de uma família de protestantes franceses emigrados, John Dollond iniciou a sua actividade de construtor de instrumentos científicos em 1758, notabilizando-se como fabricante de objectivas acromáticas. Após a sua morte, em 1761, sucedeu-lhe o seu filho Peter Dollond, que conseguiu manter os seus produtos em níveis de uma qualidade excelente. Dos instrumentos fabricados por Dollond, destacavam-se grandes quartos de círculo e círculos astronómicos, telescópios equatoriais, teodolitos, etc. Outra oficina que viria a atingir prestígio europeu foi a de Edward Nairne, fabricante de instrumentos que nasceu em 1726. Dos instrumentos que fabricava e comercializava, destacavam-se os microscópios, telescópios, bombas pneumáticas, sextantes, instrumentos de matemática, teodolitos, para além de máquinas electrostáticas e instrumentos de navegação. Refira-se que Nairne produziu uma literatura comercial abundante, através da qual promovia os seus produtos. Para além dos anteriormente citados, outros construtores ingleses que contribuíram para o prestígio da indústria 
de instrumentos científicos londrinos foram também Edmund Culpeper, James Champneys, William e Samuel Jones, etc.. Todos estes fabricantes estavam representados com vários instrumentos na magnífica colecção do Gabinete de Física Experimental da Universidade de Coimbra.

\section{As referências bibliográficas}

Dalla Bella serviu-se das obras de todos os grandes autores de livros científicos e didácticos do seu século, bem como do século XVII, utilizando-as como referências bibliográficas para a organização do seu curso de Física Experimental. Para destacar alguns, devemos citar John Teophilus Desaguliers, Willem Jacob's Gravesande, Petrus Van Musschenbroek, Jan Van Musschenbroek, Jean-Antoine Nollet, Sigaud de la Fond, Teodoro de Almeida, Joseph Priestley, entre outros. Para além destas obras, Dalla Bella recorreu também a algumas publicações periódicas, das quais destacamos Histoire de l'Academie Royal des Sciences de Paris e as Philosophical Transactions de Londres.

A literatura científica durante o século XVIII foi dominada em todo o continente pelas principais obras destes autores e instituições científicas. Com a grande revolução introduzida por Newton no final do século XVII e início do século XVIII, a sistematização das leis do movimento em três axiomas viria a constituir uma base consistente para a edificação de uma nova Mecânica, que marcaria de uma forma relevante toda a produção bibliográfica do século XVIII. Neste domínio, John Teophilus Desaguliers, natural de La Rochelle, França, viria a notabilizar-se através do seu contributo para a divulgação e desenvolvimento da Filosofia newtoniana. Por volta do ano de 1709 iniciou o ensino da Filosofia experimental no Hart Hall, até ao ano de 1712, quando se transferiu para Londres. No Inverno de 1713-1714, por sugestão de Newton, foi convidado pela Royal Society para repetir algumas das suas experiências sobre o calor. Como consequência do seu prestígio científico foi eleito fellow desta instituição no dia 29 de Julho de 1714 . A sua produção científica revelou-se importante, conforme comprovam as mais de cinquenta comunicações da 
sua autoria publicadas nas Philosophical Transactions, cobrindo áreas da Óptica, Mecânica e Electricidade. Refira-se ainda que, para além da intensa actividade científica, Desaguliers assumiu papel de destaque no plano pedagógico. A obra intitulada A Course of Experimental Philosophy, colocou-o a par de Musschenbroek e s'Gravesande, que com os seus tratados de Física Experimental contribuíram de forma significativa para o ensino da nova Filosofia nas mais prestigiadas Universidades europeias.

Para a divulgação do modelo newtoniano muito contribuíram dos membros da família Musschenbroek. Estes estabeleceram-se em Leiden, na Holanda, ainda durante o século XVII, e a sua actividade foi particularmente importante na concepção e produção de novos instrumentos científicos e didácticos. A qualidade dos seus trabalhos permitiu-lhes obter grande projecção no seio da comunidade científica europeia. Os dois primeiros membros desta família, Samuel e Johan Joosten notabilizaram-se na construção e invento de variados modelos de instrumentos científicos, em particular de microscópios e bombas pneumáticas. Jan Van Musschenbroek, filho de Petrus Van Musschenbroek, deu continuidade à obra científica do seu pai e foi o responsável pela construção dos aparelhos utilizados por s'Gravesande nas suas lições de Física. Tal como os professores de Leiden, um grande número de Universidades europeias sofreram a influência da metodologia de ensino da Física Experimental proposta por estes inovadores. O equipamento científico e didáctico criado pelos holandeses revelava-se robusto e ao mesmo tempo caracterizado por uma admirável harmonia nas suas formas. Assim, as soluções para determinados problemas de construção exigiam muita perícia e revelavam um bom gosto artístico, o que permitia transmitir à assembleia que presenciava uma lição de Física um certo bem estar. Ainda hoje os instrumentos científicos construídos no século XVIII, representativos da originalidade do equipamento desenhado pelos Musschenbroek, são objectos de admiração daqueles que os observam. Este facto pode ser comprovado pela magnífica colecção de instrumentos didácticos e científicos que na Universidade de Coimbra permitiram trazer até aos nossos dias o ambiente original de um gabinete de Física Experimental do século XVIII, fortemente inspirado nos modelos holandeses. 
Sobre Willem Jacob's Gravesande deve dizer-se que terá sido um dos precursores do ensino da Filosofia newtoniana na primeira metade do século XVIII, deixando um património bibliográfico que constituiria sempre uma das referências principais para a divulgação do novo pensamento científico. Gravesande revelou-se um seguidor de Huyghens e Leibniz no que respeita ao conceito de força viva ao afirmar no seu Essai d'une nouvelle théorie du choc des corps fondú sur l'experience, publicado no ano de 1722, que a força viva de um corpo era proporcional à sua massa multiplicada pelo quadrado da sua velocidade. Como reconhecimento da sua notoriedade científica, s'Gravesande foi eleito fellow da Royal Society no dia 9 de Junho de 1715 . No ano de 1717 , iniciou em Leyden a sua actividade como professor de Matemática e Astronomia. Em 1734 foi nomeado professor de Filosofia, inspirando a orientação do seu curso nos Principia e Opticks de Newton. A publicação dos Physica elementa mathematica, experimentis confirmata sive, introductio ad philosophian Newtonian, cuja primeira edição era de 1720, constituiu um dos referenciais mais representativos para o ensino da Filosofia Experimental da primeira metade do século XVIII. Gravesande viria a ser substituído no ensino da Física Experimental na Universidade de Leiden por Petrus van Musschenbroek, que manteria o nível do ensino desta ciência nos mais elevados padrões de qualidade científica e pedagógica.

Mas, não só a Holanda ficou assinalada pela notável obra dos Musschenbroek e de s'Gravesande. Em França, Jean Antoine Nollet e Sigaud de la Fond, entre outros, deixaram transparecer uma influência assinalável do trabalho desenvolvido por aqueles difusores da Física Experimental. Refira-se que alguns dos livros da autoria dos Musschenbroek foram traduzidos para francês. Destas traduções merecem destaque Cours de Physique Experimental et Mathematique traduzido por Sigaud de La Fond, e Essai de Physique traduzido por Pierre Massuet, ambos de Petrus Musschenbroek. De Jan Van Musschenbroek, Pierre Massuet traduziu a obra Machines Pneumatiques et Recueil d'Expériences. Refira-se ainda que a obra intitulada Éléments de Physique, da autoria de Willem Jacob's Gravesande, foi traduzida por Elie de Joncourt.

Nollet e Sigaud de La Fond notabilizaram-se como difusores da Física Experimental, tendo a sua obra o mérito de influenciar de uma forma 
positiva as metodologias de ensino desta ciência, não apenas em França, sendo reconhecida a sua importância no contexto científico europeu do século XVIII. Nas Leçons de Physique Experimentale de Nollet, uma obra em seis tomos, era desenvolvida uma perspectiva didáctica fundamentalmente baseada na experimentação. Para isso o autor recorria a instrumentos didácticos, que evidenciavam de forma magnífica os assuntos em estudo, tornando assim as lições muito motivantes. Por outro lado, Sigaud de la Fond, nos Éléments de Physique Theorique et Experimentale Pour Servir de suite à la Description et Usage d'un Cabinet de Physique Experimentale, apresentava sugestões de máquinas e aparelhos úteis para uma boa qualidade do ensino da ciência. Este investigador e pedagogo, para além de Ancien Professeur de Matemática, Demonstrador de Física Experimental, foi membro da Societé Royale des Sciences de Montpellier, das Academias de Angers, da Baviera, Valladolid, Florença, Saint Petersbourg, etc., etc.. Refira-se que até ao ano de 1824 um grande número de instrumentos adquiridos pelo Gabinete de Física de Coimbra foram concebidos a partir das ideias apresentadas por Sigaud de La Fond e de Jean Antoine Nollet, entre outros autores franceses. Nos tratados dos referidos autores podemos ficar com uma ideia de que para além do objectivo de se ensinar Física, havia uma preocupação de obediência a um estilo decorativo que prendia a atenção de quem assistia a uma lição de Física. Este facto teve a virtude de proporcionar o aparecimento de verdadeiras obras de arte, materializadas nos instrumentos destinados ao ensino e investigação em Física. No entanto, esta preocupação estética deveria marcar um ritmo mais ou menos lento de produção de instrumentos, sem que isso significasse uma vantagem sob o ponto de vista científico. Por outro lado, os custos financeiros de tal forma de produção tornavam os aparelhos demasiado caros para que o processo pudesse ser continuado. Desta forma, a preocupação do trabalho artístico associado ao desenvolvimento dos instrumentos científicos, tão marcantes no século XVIII, estava condenada. Os critérios de fabrico dos instrumentos científicos e didácticos passariam a ser fundamentalmente regulamentados pela eficiência, funcionalidade e precisão. Refira-se que alguns microscópios do século XVIII apresentavam-se como objectos de luxo, onde podiam 
ver-se bronzes elegantes e caixas ricamente trabalhadas, que não os tornava nos melhores instrumentos de observação.

\section{Dalla Bella: que inovação no ensino da Física em Portugal?}

As primeiras aulas que se deram no novo Gabinete de Física da Universidade de Coimbra foram aulas teóricas, tendo iniciado a parte experimental alguns dias depois, mais propriamente no dia 22 de Maio de 1773. D. Francisco de Lemos deu notícia deste evento numa carta em que comunicava o grande acontecimento ao Marquês de Pombal. Na sua narrativa salientou o grande fogo e ardor com que os estudantes assistiram à primeira sessão de experiências.

A exemplo do que estava determinado nos Estatutos da Universidade para a cadeira de Historia Ecclesiastica do Curso Theologico 40

... Mando ao Professor desta Cadeira, que cuide logo em ordenar, compor, e dar à estampa hum Compendio proprio, e adequado para as liçoens publicas,

também Dalla Bella procedeu à redacção do seu curso de Física. No entanto, este foi um trabalho moroso, já que apenas em 1789 teriam sido concluídos os dois primeiros volumes e em 1790 o terceiro. Na congregação da Faculdade de Philosophia de 30 de Janeiro de 1789 foi lido um aviso régio que aprovava uma parte do compêndio de Física da autoria de António Dalla Bella, sendo o resto aprovado em 8 de Maio da 1790. O compêndio intitulado Physices Elementa, redigido em latim, consta de três volumes com as dimensões $13,5 \mathrm{~cm}$ x $20,5 \mathrm{~cm}$, compondo-se na totalidade de 1168 páginas e contendo 37 folhas desdobráveis com 262 gravuras. No período compreendido entre a fundação do Gabinete de Física até à data em que foi aprovado o livro de Dalla Bella, o compêndio adoptado era o de Musschenbroek, que serviu também como importan-

${ }^{40}$ Estatutos da Universidade... Livro I, p. 46. 
te referência para a construção da colecção de instrumentos com que o Gabinete foi inicialmente equipado.

A actividade desenvolvida por Dalla Bella pode considerar-se meritória sem que, no entanto, se possa considerar absolutamente inovadora no ensino da Física Experimental em Portugal. Com efeito, o período compreendido entre o ano de 1745 e 1760 foi caracterizado por uma assinalável importância dada ao desenvolvimento do ensino da Física Experimental em Portugal. Foi o período em que os oratorianos conquistaram um lugar de destaque na cultura científica portuguesa. Na realidade, alguns elementos da Congregação do Oratório deram um contributo de relevo para a renovação da mentalidade pedagógica portuguesa, que já denotava alguns sinais de evolução ainda na primeira metade do século XVIII. Através da Recreasaõ Filozofica, bem como das Cartas Fysico-Mathematicas, da autoria de Teodoro de Almeida, publicadas depois de 1750, podemos ficar com uma informação objectiva daquilo que teriam sido os princípios orientadores do ensino científico segundo as perspectivas modernas dominantes nesta época. Para além deste aspecto, uma análise cuidada das obras deste autor torna possível obter alguma informação, embora indirecta, do que teria sido o famoso Gabinete de Física Experimental dos oratorianos, existente na Casa das Necessidades, em Lisboa. O pormenor com que nestas obras o autor descrevia as experiências que considerava mais representativas para ilustrar as teorias científicas modernas revelava um bom conhecimento das técnicas experimentais difundidas em todo o continente europeu por autores consagrados pelas mais prestigiadas Universidades e Academias Científicas. Teodoro de Almeida não deixou de utilizar todo este conhecimento nas suas lições de Física Experimental e conferências públicas. Muitos dos instrumentos científicos e pedagógicos referidos nas suas obras já teriam sido utilizados no ensino da Física Experimental na Casa das Necessidades desde meados da década de quarenta quando João Baptista, mestre de Teodoro de Almeida, introduziu o ensino desta disciplina naquela escola. Este facto leva a admitir que, mais de vinte anos antes da criação do Gabinete de Física Experimental de Coimbra, já os oratorianos, em Lisboa, e em particular Teodoro de Almeida, dispunham de magníficos meios para 
o ensino desta Ciência segundo os padrões de modernidade que dominavam as mais importantes escolas da Europa. Entre os elementos da Congregação do Oratório, aqueles que mais se destacaram no ensino das ciências físico-matemáticas foram particularmente João Baptista, Teodoro de Almeida e João Chevalier.

No Colégio dos oratorianos a prática das metodologias experimentais no ensino teriam atingido padrões de muito boa qualidade, dispondo-se para o efeito de um bem apetrechado Gabinete de Física que, porventura, poder-se-ia equiparar ao que viria a ser criado em Coimbra no ano de 1773. Alguns autores da época referiram-se de uma forma muito elogiosa a respeito da qualidade e da quantidade dos instrumentos com que estava equipado o Gabinete de Física da Casa das Necessidades, o qual sempre teve o patrocínio de D. João V, bem como, enquanto existiu, por parte de D. José I. No entanto, apesar da sua fama e importância, é desconhecido o destino que tiveram os instrumentos que fizeram parte do Gabinete de Física utilizado por Teodoro de Almeida nas suas lições, bem como do Observatório Astronómico existente na mesma escola, o qual tinha sido equipado e utilizado por João Chevalier. O facto destes importantes instrumentos terem desaparecido completamente não deixa de se revestir de uma certa aura enigmática. Na realidade, o destino pouco esclarecido de uma notável colecção de instrumentos científicos e didácticos, e consequente desmantelamento do Gabinete de Física e do Observatório Astronómico, pode ser interpretada como indício de uma intenção premeditada de se fazer cair no esquecimento factos que, de certo modo, contrariavam a ideia que se pretendia implantar de um generalizado e condenável atraso científico e pedagógico. Só deste modo se poderia justificar a ideia de uma completa inovação do ensino das matérias científicas promovida pela Reforma Pombalina dos estudos. A existência de um Gabinete de Física Experimental, com as características do que teria existido naquela escola da Congregação do Oratório de Lisboa, e utilizado com um sucesso reconhecido para fins didácticos, permitia que se colocasse em causa o carácter de inéditas atribuídas a algumas das mais importantes medidas tomadas no contexto do projecto da Reforma Pombalina do ensino das ciências. 
O século XVIII é apresentado como uma época de acesas polémicas entre oratorianos e jesuítas. Alguns críticos da actividade pedagógica dos elementos da Companhia de Jesus passaram a apresentar os oratorianos como os ilustres representantes de uma vanguarda científica e pedagógica em Portugal, em contraposição à alegada atitude obstrucionista e obscurantista dos jesuítas, estes pretensamente inscientes do progresso científico no mundo culto. Segundo estas análises, os elementos da Congregação do Oratório assumiram-se, em meados do século XVIII, como os mais vigorosos combatentes da hegemonia das escolas jesuítas. Os Colégios da Companhia de Jesus passaram a ser identificados com os projectos de ensino mais retrógrados que até então dominaram as escolas portuguesas. Por sua vez, as escolas dos oratorianos começaram a ser descritas pelos mais empenhados críticos dos jesuítas como unidades de ensino introdutoras da Ciência Moderna e como importantes centros de difusão da Filosofia Moderna. Os professores das escolas oratorianas foram identificados como fervorosos opositores dos princípios pedagógicos das escolas jesuítas, sendo estas genericamente entendidas como os grandes centros de uma obstinada defesa da Filosofia Antiga ou peripatética. No entanto, tal como os jesuítas, os elementos da Congregação do Oratório, apesar desta conotação com o pensamento científico moderno e prática pedagógica inovadora, também viriam a sofrer as consequências devastadoras do período de grandes atribulações sociais e políticas que dominaram o país desde finais da década de cinquenta.

O destino trágico dos oratorianos não foi muito diferente daquele que atingiu os jesuítas. Os propósitos de erradicação dos sectores intelectuais, considerados nefastos para a implantação de uma nova cultura científica e pedagógica, também se estenderam àqueles que foram considerados os principais antagonistas dos grandes bastiões do pensamento aristotélico, nomeadamente os jesuítas do Colégio das Artes. Na realidade, um longo processo de dificuldades, iniciado em 1760, decorrente da perseguição a que foram sujeitos os elementos da Congregação do Oratório, culminou com a extinção definitiva do Colégio da Casa das Necessidades, acontecimento que teve lugar no ano de 1768. Este longo processo de oito anos de atrofiamento da actividade pedagógica e científica dos oratorianos, 
no Colégio da Casa das Necessidades, coincidiu com o lento e infausto processo de criação do Colégio dos Nobres. Este Colégio surgiu integrado no projecto pombalino de renovação do ensino. Foi fundado por carta régia de 7 de Março de 1761. No entanto, as suas actividades lectivas apenas tiveram início a 19 de Março de 1766. Não deixa de assumir especial significado o facto deste período coincidir precisamente com os anos em que os oratorianos foram obrigados a procurar a sua segurança pessoal em refúgios afastados de Lisboa. Este retiro forçado conduziu à consequente paralisação de toda a actividade científica e pedagógica do Colégio da Casa das Necessidades. Esta paralisação viria a culminar com o provável desmantelamento do Gabinete de Física e do Observatório Astronómico aí existentes, desconhecendo-se desde então o destino da colecção de instrumentos didácticos classificada por alguns comentadores da época como sendo de excelente qualidade. A extinção de uma escola que se caracterizou por uma actividade pedagógica dedicada ao ensino das ciências, e o destino obscuro dado àquela que era considerada na época como uma magnífica colecção de instrumentos científicos não se ajusta aos propósitos de renovação do ensino das ciências físico-matemáticas que dominaram a década de setenta.

Para além da perseguição aos oratorianos, também os jesuítas do Colégio de Santo Antão tinham sido presos e expulsos no ano de 1759. Com isto, as duas escolas de Lisboa que constituíam os mais activos e importantes centros de ensino das ciências físico-matemáticas foram absolutamente paralisadas.

No entanto, apesar de todo o empenhamento dispensado pelo poder político na criação do Colégio dos Nobres, o seu programa de ensino das matérias científicas, e em particular a criação do Gabinete de Física Experimental, revelou-se um projecto que ficou assinalado por uma extraordinária e comprometedora falta de concretização dos objectivos que a envergadura do investimento justificava. Com efeito, a instalação de um excelente Gabinete de Física Experimental neste recém criado Colégio, foi um projecto ao mesmo tempo ambicioso e irremediavelmente infrutífero na utilidade que teve enquanto se manteve em Lisboa. O ensino daquela Ciência nunca chegou a acontecer verdadeiramente nesta nova escola. 
$\mathrm{Na}$ realidade, o ensino das ciências físico-matemáticas no Colégio dos Nobres ficou muito aquém do dinamismo anteriormente evidenciado ao longo de cerca de duas décadas no Colégio da Casa das Necessidades.

Enquanto a actividade científica e pedagógica na Casa das Necessidades se tinha revestido de um significativo sucesso e prestígio até ao ano de 1760, o projecto de ensino das ciências físico-matemáticas no Colégio dos Nobres foi tão efémero que não chegou a passar das boas intenções. Verificado o clamoroso insucesso em que tinha resultado a instalação do Gabinete de Física do Colégio dos Nobres, todo o seu equipamento esplendoroso foi transferido para Coimbra, facto que ocorreu em 1773. A sucessão de acontecimentos durante os atribulados anos sessenta permite concluir que foi aproximadamente um quarto de século após o início das actividades pedagógicas no Colégio da Casa das Necessidades que se tomaram as medidas que permitiram o início do ensino da Física Experimental da Universidade de Coimbra. Só em 1772 foram tomadas as medidas que repararam o fracassado projecto de ensino da Física Experimental na nova escola criada em Lisboa em 1761. No ano de 1772 concretizou-se o aparecimento da nova Faculdade de Filosofia da Universidade de Coimbra, instituição de ensino criada para substituir a então classificada como miserável Faculdade das Artes. Na nova Faculdade ficou integrado o famoso Gabinete de Física Experimental. Deste modo, a criação do Gabinete de Física Experimental da Universidade de Coimbra foi a solução encontrada para remediar o incómodo mau sucesso do projecto de ensino desta disciplina no Colégio dos Nobres. O novo Gabinete de Física de Coimbra tem sido apontado ao longo da sua história como uma das mais relevantes realizações da Reforma Pombalina da Universidade, caracterizado pela sua modernidade e grandiosidade, bem como pela sumptuosidade artística dos instrumentos com que foi equipado.

Não há conhecimento da existência de documentação que permita estabelecer qualquer relação de identidade entre a colecção de instrumentos didácticos que estiveram na origem do Gabinete de Física do Colégio dos Nobres, os quais, posteriormente, foram transferidos para Coimbra e os que fizeram parte do extinto Gabinete de Física dos oratorianos no Colégio da Casa das Necessidades. Um facto indiscutível, no entanto, é 
que não deixa de ser surpreendente a coincidência temporal do desaparecimento enigmático do Gabinete de Física dos oratorianos e a criação do Gabinete de Física do Colégio dos Nobres. Deve ser também realçado o facto de se verificar uma grande semelhança dos temas e metodologias experimentais de Física propostos por Teodoro de Almeida com os assuntos que viriam a ser ensinados em Coimbra pelo italiano Dalla Bella na Cadeira de Fysica Experimental. Uma pormenorizada análise da obra de Teodoro de Almeida, publicada até ao ano de 1768, confirma a extraordinária semelhança dos instrumentos didácticos descritos pelo oratoriano e os que equiparam o Gabinete de Física do Colégio dos Nobres, e que em 1773 foram transferidos para Coimbra.

O programa de estudos da Cadeira de Fysica Experimental que começou a ser leccionada em Coimbra evidenciava uma significativa actualidade, quando comparado com os conteúdos programáticos e metodologias de ensino praticados noutras escolas europeias. No entanto, não se pode afirmar que o projecto pedagógico concebido e executado por Dalla Bella tivesse sido tão inovador em Portugal, como uma análise superficial poderia deixar transparecer. Nos Estatutos Pombalinos ficaram bem expressos os objectivos pretendidos com o ensino das matérias científicas. Os temas que deveriam ser ensinados foram minuciosamente estabelecidos. O italiano António Dalla Bella é frequentemente apresentado como o grande introdutor do ensino da Física Experimental em Portugal. No entanto, tomando como referência o conteúdo programático que viria a ser colocado em prática no Gabinete de Física Experimental, criado em Coimbra com a Reforma Pombalina, pode concluir-se que, de um modo geral, quase todos os assuntos desta Ciência também já tinham, algumas décadas antes, feito parte da matéria de ensino em diversos cursos orientados por vários professores portugueses. Entre estes, assumiram uma grande importância os nomes de Teodoro de Almeida e Inácio Monteiro. Este argumento pode ser demonstrado através de um pormenorizado estudo das obras publicadas por estes professores, alguns anos antes da Reforma de 1772. ${ }^{41}$

41 Décio R. Martins, ob. cit. 
O Physices Elementa, da autoria de Dalla Bella, foi a primeira obra literária de carácter científico e didáctico, no âmbito da Física Experimental, resultante do projecto pedagógico iniciado com a Reforma Pombalina da Universidade. As referências bibliográficas mais importantes que Dalla Bella utilizou já tinham sido objectos de estudo e de debate, ainda na primeira metade do século XVIII, em diversos cursos das escolas portuguesas. O compêndio, destinado ao ensino, foi publicado aproximadamente quarenta anos depois de Teodoro de Almeida publicar em Lisboa os primeiros volumes da Recreasaõ Filozofica, e de Inácio Monteiro concluir a publicação do Compendio dos Elementos de Mathematica no Colégio das Artes em Coimbra. Tendo como referência estes factos, conclui-se que os anos conturbados que se seguiram à extinção dos Colégios das Artes, de Santo Antão, e do Colégio dos oratorianos instalado na Casa das Necessidades terão sido pouco produtivos e marcados por uma profunda ausência de inovação no ensino teórico e experimental da Física. $\mathrm{Na}$ realidade, foi muito longo o período que decorreu entre as publicações das primeiras edições da obra de Teodoro de Almeida, e da publicação da obra de Inácio Monteiro, até que o Compêndio de Dalla Bella surgisse como um produto do projecto pedagógico iniciado em 1772. Por sua vez, Teodoro de Almeida manteve uma actividade editorial notável. Até 1800 apenas não publicou obras de relevo durante o seu exílio. ${ }^{42}$

Quanto aos assuntos de natureza científica, bem como às referências bibliográficas dos autores europeus mais consagrados, verifica-se que pouca ou nenhuma inovação foi introduzida por Dalla Bella através do compêndio que deixou publicado em 1789/1790. A lista de autores clássicos e modernos que poderia ser elaborada a partir das referências bibliográficas contidas na obra Teodoro de Almeida, publicada entre 1751 e 1768, e de Inácio Monteiro, publicada em 1754 e 1756, era equiparável à registada no compêndio de Dalla Bella. Todos os grandes autores da primeira metade do século XVIII, referidos por Dalla Bella, já há algumas décadas antes eram do conhecimento do oratoriano Teodoro de Almeida e do jesuíta Inácio Monteiro. Com efeito, os compêndios destinados aos

\footnotetext{
42 Idem, ibidem.
} 
cursos de Física Experimental, utilizados nas mais importantes universidades europeias, da autoria de John Teophilus Desaguliers em Inglaterra, Petrus van Musschenbroek e Willem Jacob's Gravesande em Leyden, na Holanda, bem como de Noel Regnault e Jean Antoine Nollet em França, fizeram parte de uma numerosa e extraordinária lista de obras de literatura científica que também foram importantes referências bibliográficas para o desenvolvimento do ensino em Portugal, algumas décadas antes de 1772. As mais importantes obras destes autores também foram utilizadas como referências bibliográficas por Teodoro de Almeida e Inácio Monteiro nas suas lições.

Por outro lado, alguns assuntos recomendados como matéria de ensino para a cadeira de Fysica Experimental do Curso de Philosophia, criada em 1772, não foram contemplados nas obras de Teodoro de Almeida e Inácio Monteiro, publicadas antes da Reforma Pombalina. São exemplos deste facto os assuntos relativos à Electricidade e ao Magnetismo. No entanto, isto não significava, necessariamente, um desconhecimento dos assuntos. Teodoro de Almeida declarou que optava por não os incluir na Recreasã̃ Filozofica, por considerar que os conhecimentos que naquela época se tinham sobre estas matérias eram ainda muito especulativos.

\section{A complementaridade científica e pedagógica das Faculdades de Filosofia e de Mathematica}

Com a Reforma Pombalina da Universidade de Coimbra foram criadas as Faculdades de Filosofia e de Mathematica. Os planos de estudos das duas Faculdades apresentavam características complementares na formação científica dos estudantes. Com efeito, os estudantes do Curso Filosófico adquiriam conhecimentos fundamentais em Mathematicas Puras na Faculdade de Mathematica, antes de frequentarem a cadeira de Fysica Experimental e Chimica Theorica e Pratica, leccionadas na Faculdade de Filosofia. Posteriormente, davam continuidade aos seus estudos nos aspectos teóricos da Física frequentando a cadeira de Phoronomia, integrada no $4^{\circ}$ ano do plano curricular do Curso Mathematico. Por sua 
vez, os estudantes da Faculdade de Mathematica também frequentavam a cadeira de Fysica Experimental, leccionada no Curso Filosofico. Tanto para os estudantes do Curso de Filosofia como para os de Matemática, a frequência desta cadeira era considerada uma base indispensável para os estudos posteriores das Sciencias Fysico-Mathematicas.

Nos Estatutos Pombalinos da Universidade de Coimbra o conjunto das ciências Fysico-Mathematicas era considerado um ramo do conhecimento que tinha uma perfeição indisputável entre todos os conhecimentos naturais, caracterizada pela exactidão do método, bem como pela sublime e admirável profundidade de análise das suas doutrinas. Pelas suas características particulares, justificava-se que o seu estudo fosse considerado indispensável como preparatório para a formação de todos os estudantes em geral. Através do método das ciências matemáticas o entendimento de qualquer outra disciplina poderia atingir um elevado estágio de desenvolvimento. O contributo das ciências matemáticas para as outras disciplinas concretizava-se, ${ }^{43}$

... mostrando-lhe praticado o exemplo mais perfeito de tratar huma materia com ordem, precisão, solidez, e encadeamento fechado, e unido de humas verdades com outras: Inspirando-lhe o gosto, e descernimento necessario para distinguir o Solido, do Frivolo; o Real, do Apparente; a Demonstração, do Paralogismo: E participando-lhe huma exactidão, conforme ao Espirito Geometrico; qualidade rara, e preciosa, sem a qual não podem conservar-se, nem fazer progresso algum os conhecimentos naturaes do Homem em qualquer objecto que seja.

Conforme ficou estabelecido nos Estatutos de 1772 criava-se e estabelecia-se a Profissão Mathematica na Universidade de Coimbra em Corpo de Faculdade, fundamentada pela importância que assumia o estudo das Sciencias Mathematicas. Pela exactidão exemplar das suas disciplinas, esta nova Faculdade deveria servir como modelo de referência

43 Estatutos da Universidade... Livro III, Segunda Parte - Do Curso Mathematico, p. 141-142. 
a todas as outras Corporações. Na Faculdade de Mathematica deveriam adquirir a sua formação académica não só aqueles estudantes cujo talento os levasse a prosseguir nos conhecimentos matemáticos, mas também os que se destinassem a cursos que menos analogias pareciam apresentar com o objecto da Mathematica. A frequência das cadeiras preparatórias no Curso Mathematico era considerada indispensável porque através do estudo desta ciência os estudantes em geral adquiriam o hábito de combinar as ideias com rigor científico, ficando aptos a desenvolver o seu raciocínio, evoluindo com exactidão das verdades mais simples, até às mais complexas, por uma cadeia de elaborações intelectuais eficazes, tanto sintéticas, como analíticas. Sendo assim, determinava-se que o Curso Mathematico fosse frequentado por diferentes classes de ouvintes, que recebiam instrução adequada que os preparava para darem seguimento nas diversas opções de estudos universitários. Existiam três ordens de ouvintes: os ordinários, os obrigados e os voluntários. Os estudantes ordinários eram aqueles que se destinavam a fazer os seus estudos completos no Curso Mathematico, para serem nele formados, ou graduados. Era especificamente para estes estudantes que o curso estava estruturado. Os estudantes obrigados eram aqueles que, provenientes de outros cursos, deveriam estudar as Sciencias Mathematicas como subsídio e preparação para a prossecução dos estudos nos cursos das respectivas Faculdades. Eram obrigados a frequentar os três primeiros anos do Curso de Mathematica os estudantes de Medicina. Os estudantes dos Cursos Jurídico e Theologico também eram obrigados a frequentar privativamente o Curso Mathematico, onde adquiriam conhecimentos sobre os Elementos de Geometria e aprendiam a Lógica, ${ }^{44}$

... praticada com a maior perfeição, que he possivel ao entendimento do homem; cujo exemplo he mais instructivo, do que todas as Regras, e Preceitos, que se podem imaginar, para dirigir, e encaminhar o discurso.

Para além dos Elementos de Geometria, os estudantes dos Cursos Jurídico e Theologico deveriam também frequentar, no primeiro ano a

${ }^{44}$ Idem p. 151-152. 
Filosofia Racional e Moral, e no segundo ano a Historia Natural do Curso Filosofico. Apenas depois de terem cumprido estes dois anos de estudo poderiam matricular-se nas respectivas Faculdades.

Os voluntários eram os estudantes que apenas pretendiam instruir-se por curiosidade, sem que se destinassem ao estudo de qualquer curso universitário. A todos era sempre oferecida a possibilidade de poderem adquirir conhecimentos que satisfizessem a sua curiosidade, apenas para ornamento do seu espírito, como convinha a todas as classes de pessoas, principalmente à nobreza. Para estes ouvintes era-lhes facultado o acesso às lições, ficando livres das pensões anexas aos estudantes ordinários e obrigados.

Relativamente à idade de ingresso no Curso Mathematico, os Estatutos Pombalinos da Universidade de Coimbra estabeleciam que: ${ }^{45}$

... ainda que não póde assignar-se hum termo fixo da evolução da Razão, que he necessaria para estas Sciencias; por ter mostrado a experiencia, que ella se antecipa em huns, e retarda em outros; escolhendo com tudo o limite mais ordinario, além do qual não costuma retardar-se a referida evolução na maior parte dos homens: Sou servido ordenar, e estabelecer, que ninguem seja admitido às Lições públicas de Mathematica, em qualquer das Classes assima referidas, antes de ter quinze annos completos de idade;...

Uma particularidade que se considerava demonstrar as maiores vantagens e a excelência da Mathematica era a sua independência de todas as outras ciências. A Mathematica possuía método, princípios, lógica e metafísica específicas, cujo exercício intelectual tornava o entendimento de todas as outras Artes e Faculdades mais eficazes, sem que, no entanto, o seu próprio entendimento estivesse dependente de outras doutrinas. Desta forma, a matrícula no Curso Mathematico não estaria condicionada pela frequência prévia de qualquer outro curso. Apenas se exigia o conhecimento da língua latina, recomendava-se o conhecimento da língua grega, 
bem como do francês e de inglês. Os estudantes do Curso Mathematico estavam obrigados a frequentar um ano de Filosofia Racional e Moral, juntamente com a Histora natural, do Curso Filosofico. Depois deste ano deveriam frequentar, no segundo ano, a cadeira de Fysica Experimental, sendo obrigados a fazer os exames nas respectivas cadeiras.

O estudo da Mathematica tinha por objecto as relações e propriedades da quantidade ou grandeza. Segundo afirmavam os Estatutos, ${ }^{46}$

... não havendo no Mundo algum objecto sensivel, que não seja Quanto, e não tenha certas propriedades de grandeza relativas a outros objectos do mesmo genero; pois que todas as partes do mesmo Mundo foram constituidas pelo Eterno Geometra em numero, pezo, e medida: He manifesto, que não tem esta vasta Sciencia outros limites, que não sejam; na especulação, os do entendimento humano; e na applicação, os do Universo.

A vastidão dos temas que constituíam objecto de estudo das Sciencias Mathematicas levava à necessidade da distinção das matérias em ramos específicos, para que o seu tratamento fosse feito com ordem e eficiência. A sua divisão numa considerável multiplicidade de diferentes disciplinas tinha por critério o objecto específico de cada uma delas. A Algebra era considerada a primeira Sciencia Matbematica, na qual eram tratadas as propriedades e relações da grandeza em geral. Nesta ciência estavam contidos os princípios fundamentais da análise, que era tido como um instrumento fundamental para o desenvolvimento da Mathematica. No seu estudo eram considerados não apenas os estados particulares e finitos, mas também as variações e fluxões instantâneas. A primeira classificação considerada para a Quantidade era a das quantidades discretas e as contínuas. Esta divisão dava origem a dois ramos principais da Mathematica: A Arithmetica e a Geometria. No primeiro ramo procedia-se ao estudo do número. Na Geometria tratava-se da extensão, estudo que tinha como conceitos fundamentais o comprimento, largura e profundidade. Um importante ramo da Geometria era a Trigonometria, tanto rectilínea como 
esférica, que constituíam um instrumento indispensável para o estudo da Geodesia, Stereometria, Aerometria, Hydrometria, etc.

A Álgebra, Arithmetica e a Geometria estavam incluídas na classe das ciências Mathematicas Puras. Por sua vez, as Sciencias Fysico-Mathematicas, que formavam o conjunto das Mathematicas Mixtas, tinham por objecto de estudo os aspectos quantitativos dos fenómenos da Natureza, considerando-se a quantidade das grandezas físicas nas suas divisões e subdivisões mais particulares. Todas as Sciencias Fysico-Mathematicas se reduziam à Phoronomia, ciência geral do movimento dos corpos. De acordo com os Estatutos da Universidade, esta era a ciência que continha a melhor parte da Fysica, por ser o movimento o agente principal de todos os Fenomenos, como alma da mesma Natureza. ${ }^{47}$ O estudo geral do movimento dos corpos encontrava-se dividido em vários ramos, em cada um dos quais era considerado o movimento dos corpos, cuja natureza exigia uma metodologia própria e particular. Deste modo, o movimento, ou a tendência para o movimento dos corpos sólidos era o objecto da Estática, Mecânica, Dynamica e Ballistica. Por sua vez, o estudo do movimento dos fluidos era contemplado na Hydraulica, Hydrostatica e Hydrodinamica. O movimento da luz era objecto de outro conjunto de ciências, tendo, cada uma delas, um tratamento específico: a Optica, Dioptrica, Catoptrica e Perspectiva. A Astronomia tinha por objecto o estudo do movimento dos astros, sendo a base de um conjunto diversificado de ciências, como sejam a Cosmografia, Geografia, Hydrografia, Gnomonica, Chronologia, Pilotagem, etc. Também fazia parte do conjunto das Mathematicas Mixtas o estudo do movimento do som, o qual dava origem à Acustica, Phonocamptica, Melodia, Harmonia. Era previsível que o desenvolvimento do conhecimento científico originasse novas classes de Mathematicas Mixtas, onde seriam estudados outros movimentos particulares, que entretanto viessem a ser descobertos.

A diversidade de ciências que constituíam o conjunto das Mathematicas Puras e Mathematicas Mixtas dava origem a um extenso corpo de

${ }^{47}$ Idem p. 163. 
conhecimentos, cujo tratamento profundo tornava inviável que o seu estudo ficasse limitado no período de quatro anos do Curso Mathematico. Deste modo, o estudo das referidas ciências não poderia ir para além dos princípios fundamentais de cada uma delas. Assim, a profundidade dos estudos deveria ser a necessária e indispensável para que o estudante pudesse, por si mesmo, dar continuidade ao desenvolvimento posterior dos seus conhecimentos. Tendo por base o critério da formação que preparasse o estudante para o desempenho autónomo na progressão e aplicação dos seus conhecimentos, o Curso Mathematico tinha distribuído ao longo de quatro anos um conjunto de quatro cadeiras que serviam de base para as ciências mais específicas. A primeira cadeira era a de Geometria, onde se ensinava no primeiro ano os Elementos de Arithmetica, Geometria e Trigonometria Plana, com as respectivas aplicações à Geodesia, Stereometria, etc. O segundo ano estava destinado ao estudo da Algebra, a qual contemplava o estudo do Cálculo Literal, ou Algebra Elementar, e os princípios do Cálculo Infinitesimal Directo e Inverso, considerando também a sua aplicação à Geometria Sublime e Transcendente. O estudo geral dos movimentos fazia-se no terceiro ano, na cadeira de Phoronomia. Nesta cadeira eram abordados todos os ramos desta ciência, que constituía o corpo das Sciencias Fysico-Mathematicas, como a Mecânica, Statica, Dynamica, Hydraulica, Optica, Dioptrica, etc. Por fim, no quarto ano ensinava-se, na cadeira de Astronomia, a teoria do movimento dos astros. Neste estudo estavam contemplados tanto os aspectos físicos como geométricos, procedia-se à prática do cálculo, observações astronómicas, bem como eram desenvolvidos os estudos relativos às ciências que dependiam da Astronomia. Para além destas quatro cadeiras, os estudantes deveriam também frequentar uma cadeira de Desenho Civil e Militar. Esta cadeira, no entanto, não era considerada com o mesmo estatuto das restantes, por se considerar que nestas artes não havia a exactidão matemática que caracterizava todas as outras cadeiras que faziam parte do curso. Tratava-se de uma cadeira cujo ensino se desenvolvia através de um grande número de regras arbitrárias, e regia-se mais pelo bom gosto, do que pela demonstração. 


\section{As matemáticas puras}

O ensino na cadeira de Geometria tinha início com a leitura dos Prolegomenos Geraes das Sciencias Mathematicas, onde eram apresentados de uma forma breve e substanciada o método, a divisão e o conteúdo programático de cada uma delas. A esta nota introdutória seguia-se uma descrição da evolução histórica, colocando em realce algumas épocas notáveis do pensamento científico. Evoluía-se desde a origem da Mathematica até ao século de Thales e Pitágoras, passando pela fundação da Escola Alexandrina, prosseguindo pela Era Cristã, referindo o período que culminou com a destruição do Império Grego, e daí até à época de Descartes, finalizando com os contemporâneos. A abordagem histórica deveria ser feita de um modo adequado ao conhecimento dos estudantes, e tinha por objectivo desenvolver o estímulo para o estudo destas ciências. Para isso, deveria evitar-se uma exposição circunstanciada dos acontecimentos que ocorreram em diferentes épocas da história da ciência. Argumentava-se que uma perfeita interpretação dos acontecimentos históricos apenas poderia ser possível depois de um desenvolvido estudo da matéria científica. No entanto, deveria ser uma preocupação constante do lente, que transmitisse aos estudantes que ${ }^{48} \ldots$

... a primeira cousa, que deve fazer quem se dedica a entender no progresso das Mathematicas, he instruir-se nos descubrimentos antecedentemente feitos; para não perder o tempo em descubrir segunda vez as mesmas cousas; nem trabalhar em tarefas, e emprezas já executadas.

Depois deste estudo introdutório, o lente iniciava o tratamento das disciplinas próprias do primeiro ano, começando pela Arithmetica, considerada como estudo fundamental para o subsequente desenvolvimento dos estudos matemáticos. Com a brevidade possível, o lente explicava distintamente o objecto, a sua origem e os progressos da ciência. Através de uma breve abordagem histórica os estudantes eram confrontados com a dificuldade

\footnotetext{
48 Idem p. 170.
} 
com que os antigos faziam as operações numéricas, problema que teve a sua resolução com a invenção dos caracteres aritméticos, vulgarmente designados arábicos. A análise deste processo histórico era tomado como exemplo para tornar evidente e bem sensível a importância que a representação simbólica assumia para o estabelecimento da ordem e clareza das ideias. Com efeito, os símbolos bem imaginados serviam com indiscutível vantagem ao desenvolvimento do conhecimento, permitindo combinar as ideias com prontidão e facilidade. Os conceitos do número e da unidade surgiam como tema preliminar do estudo da Arithmetica. Estes temas preliminares e fundamentais apresentavam-se com uma envolvente metafísica. O lente deveria explicar que a unidade era quase sempre arbitrária e hipotética, e servia de termo e medida ao número. Adquirido o conceito de número passava-se ao desenvolvimento exacto e claro da ideia fundamental da numeração. Neste estudo pretendia-se distinguir o que nela havia de natural e de arbitrário. Enunciavam-se os princípios que lhe deveriam servir para a demonstração das quatro Regras Fundamentaes, cujo algoritmo era mostrado nos Numeros Simplices, e Complexos; Inteiros e Quebrados; tanto Ordinarios, como Decimaes, Sexagesimaes, Ec. Constituía um objectivo deste estudo que os estudantes aprendessem não apenas as regras de cálculo, mas também a razão científica em que se fundavam. Após o estudo das regras fundamentais do cálculo, tinha lugar a teoria e prática da formação dos números quadrados e cúbicos, a extracção das suas raízes; as propriedades fundamentais das proporções e progressões, tanto aritméticas como geométricas. Procedia-se ao estudo das regras mais utilizáveis, como a regra de três simples e composta; directa e inversa; regras de falsa posição, de sociedade, de liga, Ec. O estudo da teoria dos números contemplava também a ideia fundamental dos números artificiais e subsidiários, designados pelo nome de Logarithmos. Neste estudo eram enunciadas as suas propriedades e demonstrado o seu uso vantajoso nas operações numéricas ${ }^{49}$,

... convertendo-se por este engenhoso artifício as Multiplicações em Addições; as Divisões em Subtracções: E extrahindo-se com summa

49 Idem p. 172. 
facilidade todas, e quaisquer Raizes Numericas, que pelos methodos ordinarios, e nos gráos superiores involvem Operações de immenso trabalho.

Após o estudo da teoria dos números, o lente dava início à exposição das matérias relativas à Geometria Elementar, dando-se especial ênfase aos Elementos de Euclides, aos quais se juntavam os Theoremas de Archimedes. Seguia-se o ensino da Trigonometria Plana. Estes estudos eram considerados de importância fundamental, pois todo o estudo subsequente estaria muito dependente dos conhecimentos adquiridos nesta ciência. Tal como preconizavam os Estatutos: ${ }^{50}$

... nella se deve costumar o entendimento a sentir a evidencia dos raciocinios Mathematicos; procurar a exactidão, e rigor Geometrico das Demonstrações; e a pensar methodicamente em qualquer materia.

No segundo ano os estudantes frequentavam a cadeira de Algebra, na qual se ensinava Cálculo Algebraico, tanto Elementar, como Infinitesimal, com a correspondente aplicação à Geometria Sublime e Transcendente. Numa breve abordagem histórica o lente mostrava a razão porque os Antigos, apesar de terem conhecido as regras fundamentais da análise e de serem dotados de tão grande engenho, não tiraram delas todas as vantagens, como o tinham feito os Modernos. Na realidade, teria faltado aos Antigos a arte de representar por símbolos gerais todas as ideias que se formam no espírito, relativamente às quantidades. Destes símbolos dependia a facilidade de combinar as ideias, e de alcançar o resultado de conhecimentos tão distantes das verdades elementares, que não seria jamais possível chegar a descobri-los por qualquer outro caminho. Eram considerados três pontos capitais, a que se reduzia todo o estudo da Algebra, que a seguir se enunciam:

- saber exprimir todas, e quaisquer circunstâncias, relações e condições das quantidades em linguagem algébrica.

- saber discorrer e combinar as mesmas condições umas com as outras, fazendo sobre elas todas as operações necessárias para o fim que se intenta.

50 Idem p. 172. 
- saber interpretar o resultado final de um problema, em que consiste a resolução dos problemas, ou a invenção de teoremas.

As matérias de estudo da cadeira do segundo ano do Curso Mathematico começavam pelas operações fundamentais do cálculo literal, nas grandezas simples, complexas e fraccionárias, tanto racionais, como irracionais; na formação das suas potências, e extracção das raízes; explicando com distinção os diferentes modos de exprimir, reduzir e transformar as mesmas grandezas. O estudo realizado neste domínio contemplava o tratamento das equações, e suas propriedades, tanto gerais, como particulares. Mostravam-se os melhores métodos conhecidos para a sua resolução, recorrendo às diferentes preparações e transformações de que eram passíveis, com o objectivo de as reduzir e resolver com mais facilidade. Era na cadeira de Algebra que se desenvolvia o estudo das Séries, tendo em conta os respectivos métodos de transformação e conversão em outras. Nos Estatutos Pombalinos podemos ler o seguinte: ${ }^{51}$

Tendo deste modo instruido, e exercitado completamente os seus Discipulos nas Operações do Cálculo Literal sobre toda a sorte de quantidades, e Expressões Algebricas; passará a explicar-lhes as Regras Fundamentais da Analyse: Mostrando, como se devem exprimir as condições dos Problemas; como se hão de combinar as Equações primitivas, que dellas resultam; até chegar a concluir huma Equação, na qual se determine a relação da quantidade desconhecida com outras todas conhecidas; e finalmente como se deve interpretar a resolução da Equação final de qualquer problema; distinguindo bem o significado dos Valores positivos, negativos, indeterminados, imaginarios, \&c.

Na sequência deste estudo, o lente da cadeira não deveria deixar de apresentar aos seus discípulos exemplos de aplicação da Analyse à Arithmetica e Geometria Elementar. Para o efeito, recorria a um número suficiente e criterioso de problemas, tanto determinados, como indeterminados, através dos quais os estudantes exercitavam os seus conhecimentos

51 Idem p. 177. 
teóricos, até adquirirem o hábito de aplicar com facilidade e destreza as regras gerais da Analyse aos casos particulares. Neste âmbito eram tratadas as Progressões Arithmeticas e Geometricas, dos Números Figurados, Séries Recorrentes, etc.

O estudo da Algebra Elementar concluía-se com o Tratado Analytico das Curvas, também designadas por Secções Conicas. Neste capítulo eram tratadas as propriedades gerais e particulares da Parabola, Elipse $e$ Hyperbole. Era explicado particularmente a doutrina dos lugares geométricos, a construção das equações que geometricamente se resolvem por meio das referidas curvas.

Na segunda parte da cadeira do segundo ano do Curso Mathematico era feito um estudo desenvolvido da Algebra Infinitesimal, a qual estava dividida em dois ramos: Cálculo Differencial e o Cálculo Integral. No Cálculo Differencial estudavam-se os Fluxões ou Elementos Infinitesimais. A metodologia de ensino utilizada tinha por objectivo tornar evidente que os resultados deste cálculo eram tão rigorosos e exactos como os da Geometria Elementar. Os graus de abstracção exigidos nestas duas ciências tinham alguma analogia entre si. Com efeito, os conceitos de ponto, sem grandeza, a linha, sem largura e a superfície, sem profundidade, não eram entidades reais e absolutas, mas sim ideias hipotéticas a partir das quais se edificava com toda a exactidão a estrutura da Geometria Elementar, a qual era aplicável com sucesso à extensão real dos corpos. Do mesmo modo, as variações e os elementos infinitesimais deveriam ser considerados entidades não reais e absolutas, mas, igualmente, como ideias hipotéticas que constituíam a base de desenvolvimento de uma ciência matemática exacta, o Cálculo Differencial. Nos Estatutos Pombalinos afirmava-se que: ${ }^{52}$

Tambem mostrará, que o desprezarem-se neste Cálculo as Differenças do Segundo Gráo, em comparação das do Primeiro; e assim por diante; tão longe está de ser falta de exactidão, que antes nisso he que consiste toda a exactidão do mesmo Cálculo: Porque a condição de se supôr, que

52 Idem p. 179. 
hum Elemento tem chegado ao estado Infinitésimo, não póde já mais fixar-se, nem estabelecer-se, senão fazendo desvanecer em comparação delle os Elementos de Gráo superior; os quaes, em quanto tiverem entre si razão alguma assignavel, não terão chegado ao estado Infinitesimal, que por hypothese devem ter para a exactidão dos resultados, que das suas relações, e propriedades se hão de deduzir.

Nas lições de Cálculo Differencial os estudantes eram familiarizados com as regras fundamentais da Differenciação em todo o tipo de expressões e funções algébricas, exponenciais, logarítmicas, trigonométricas, etc. Depois de adquirirem um perfeito domínio e destreza no cálculo de qualquer expressão que lhes fosse proposta, os estudantes iniciavam a aprendizagem que os tornassem aptos a aplicar todo o conhecimento previamente adquirido no estudo da Theorica Geral da Curvas. Neste capítulo aprendiam o método de determinar as tangentes, sub tangentes, normais, sub normais, raios de curvatura. Procediam ao cálculo dos pontos máximos e mínimos, bem como a identificação dos pontos múltiplos e de inflexão. Determinavam as Evolutas e Envolventes, Cáusticas por Reflexão e Refracção.

Ao estudo do Cálculo Differencial seguia-se o estudo do Cálculo Integral. Sobre a importância deste estudo, os Estatutos afirmavam que: 53

Do Cálculo Differencial passará finalmente ao Integral. He este de tão grande importancia, que se assim como ha Regras para differenciar toda, e qualquer Expressão Algebraica, as houvesse para integrar toda, e qualquer Expressão Differencial; não haveria mais que desejar nas Sciencias Mathematicas. Esta falta de Regras Geraes faz toda a difficuldade desta ultima parte da Analyse: Sendo necessario imaginar varios, e diferentes methodos para conseguir a Integração de algumas Expressões, e Formulas particulares. No que se tem feito alguns descubrimentos, e restam ainda muitos para fazer.

53 Idem p. 180. 


\section{As ciências Físico-Matemáticas}

No terceiro ano do Curso Mathematico, e depois da frequência da ca-deira de Fysica Experimental na Faculdade de Filosofia, os estudantes frequentavam na Faculdade de Mathematica a cadeira de Phoronomia, considerada a ciência geral do movimento. Os seus objectos de estudo eram tanto os sólidos como os fluidos, a partir dos quais se definiam todos os ramos subalternos das Sciencias Fysico-Mathematicas. Estes ramos eram a Statica, Hydrostatica, Mecanica, Dioptrica, Catoptrica, e todos os ramos da ciência onde eram tratados os fenómenos e efeitos que de qualquer modo resultassem do movimento dos corpos, os quais podiam ser caracterizados através do Cálculo e da Geometria. Nos Estatutos Pombalinos pode ler-se que: ${ }^{54}$

Em todos estes Tratados se contém a parte mais sublime da Fysica, promovida de hum modo scientifico, e util ao progresso, e perfeição das Artes, cujo instrumento he o mesmo Movimento. Os Filosofos, que não possuem as Mathematicas com a profundidade necessaria, não passam das Sciencias do Movimento, mais que pela superficie. Contentam-se de raciocinar em geral sobre os Fenomenos, e effeitos: Procurando descubrir as causas delles. Mas sendo por sua natureza muito vacilante esta especie de raciocinio; e faltando-les a Sciencia de calcular exactamente os ditos effeitos, para ver se correspondem às causas suppostas; ficam sempre vagando no paiz das conjecturas.

Além disso, ainda que raciocinando ao acaso se acerte alguma vez com a verdadeira razão dos Fenomenos; a verdade conhecida não passará já mais de huma pura especulação, quando faltarem os methodos mais efficazes da Analyse Mathematica: Porque sem esta não póde fazer-se uso algum dos ditos conhecimentos especulativos para resolver qualquer Problema de Fysica, em que se peção as condições, e circumstancias necessarias, para resultar dellas hum effeito determinado.

${ }^{54}$ Idem p. 182. 
Tendo como princípio este argumento, justificava-se que a Fysica da quantidade, ou as Sciencias Fysico-Mathematicas, fossem ensinadas no Curso Mathematico. A formação do estudante nesta área do conhecimento, no entanto, apenas deveria ocorrer depois de uma adequada preparação fundamental nas Sciencias Exactas e frequência da cadeira de Fysica Experimental da Faculdade de Filosofia. A Mathematica deveria ser entendida como a essência de todo o desenvolvimento da Fysica, exceptuando sempre os princípios fundamentais, que deveriam ter como origem a experiência. Deste modo, justificava-se que os estudantes do Curso Mathematico frequentassem no terceiro ano as lições de Fysica Experimental, do Curso Filosofico. Pretendia-se com o referido plano de estudos que, através da Analyse Mathematica, se pudessem extrair todas as consequências possíveis dos princípios mostrados de facto pela via experimental, e que reunissem os requisitos necessários para se edificar sobre eles um corpo de ciência.

Para a definição de uma metodologia de ensino que se revelasse eficaz, o professor dedicava especial cuidado na explicação clara e distinção possível dos princípios fundamentais, tanto gerais, como particulares, de cada um dos vários domínios da ciência geral dos movimentos. A evolução do ensino era feita...55

... subindo dos ditos Princípios por meio de huma cadeia de raciocinios Mathematicos, fundados, e dirigidos pelos methodos mais eficazes do Cálculo, e da Geometria; conduzirá os seus Ouvintes até às ultimas consequencias, a que póde chegar a industria do homem nestas materias; tendo sempre grande attenção a mostrar nos lugares competentes a resolução dos Problemas, que forem de alguma importancia para o adiantamento, e perfeição das Artes.

Como o progresso destas Sciencias consiste em alargar-lhes os limites, em que de huma, e outra parte se terminam: Procurará o Professor, não sómente remontar-se, levando adiante as consequencias, e descubrindo nellas novos usos, e combinações; mas tambem retroceder;

55 Idem p. 183-184. 
analyzando, e generalizando os seus Principios; descendo até encontrar os que indisputavelmente sejam os primeiros nas ditas Sciencias; e excluindo todos aquelles, que forem escuros, e inuteis.

Os assuntos tratados na cadeira de Pboronomia começavam pelo estudo das forças. Neste estudo, o professor não deveria fazer qualquer exame da essência das forças motrizes, que era considerada uma análise metafísica e obscura, que não tinha outro resultado que não fosse o da introdução de conceitos nublados, que apenas davam origem a confusões num corpo de conhecimentos que se pretendia claro e evidente. Deste modo, o estudo que se pretendia fosse isento de situações dúbias, teria por objecto a análise dos efeitos das forças. Os princípios sobre os quais se fundava o estudo da ciência dos movimentos eram:

- A inércia dos corpos.

- A composição e decomposição do movimento.

- O equilíbrio de dois corpos iguais em distâncias iguais do eixo de movimento.

Tendo como referência estes princípios mostravam-se as leis do equilíbrio de quaisquer potências mecânicas, aplicadas em qualquer número, e em qualquer condição, sobre um corpo flexível, ou inflexível. Este estudo fazia-se deduzindo teoremas, indicando o método de resolução de problemas Fysico-Mathematicos, determinando a configuração de cordas suspensas pelas suas extremidades, das velas impelidas pela acção do vento, etc.

Também estavam incluídos no programa de ensino da cadeira de Phoronomia os seguintes temas:

\section{- Estudo das propriedades dos movimentos.}

Neste capítulo eram tratados o movimento uniforme e o movimento variado de qualquer espécie. Este conhecimento era aplicado na Theorica do centro de gravidade, e centro de forças, ou potencias, onde eram analisados os aspectos relacionados com a velocidade, os espaços percorridos, tempos de movimento. Para além do movimento de translação, era também dado um significativo desenvolvimento à Theorica da rotação de qualquer sistema de corpos livres, ou ligados entre si por 
linhas flexíveis ou inflexíveis. Neste estudo estabeleciam-se relações quantitativas dos ângulos descritos em função das potências actuantes. Como exemplo particular deste estudo fazia-se referência ao movimento angular das alavancas, considerando também a resistência que deveriam ter as fibras de que eram constituídas.

- Teoria da percussão dos corpos moles, duros e elásticos.

O estudo da teoria da percussão fazia-se considerando os aspectos quantitativos que permitiam determinar os tempos, as velocidades, os espaços percorridos e as interacções entre os corpos ocorridas durante a percussão. Como desenvolvimento deste estudo eram analisados os movimentos dos corpos solicitados por quaisquer forças, tanto livres, como sujeitos a ligações. Neste domínio era dada especial ênfase ao estudo do movimento ao longo de planos inclinados, ou por quaisquer linhas curvas. Eram particularmente analisados os movimentos dos projécteis, pêndulos simples, compostos, determinando a linha isócrona em qualquer hipótese da gravidade.

\section{- Teoria das forças centrais.}

Neste capítulo os estudantes eram particularmente sensibilizados para a importância deste conhecimento para o entendimento dos movimentos planetários. Sendo a Astronomia a cadeira que correspondia ao quarto ano do Curso Mathematico, justificava-se que a teoria das forças centrais tivesse um desenvolvimento particular e específico. Era neste capítulo que os Estatutos previam a inclusão de um estudo onde se explicava a teoria das Máquinas simpleces, e compostas, tendo em consideração a fricção, resultantes da rigidez, aspereza e gravidade das suas partes. Procedia-se ao cálculo das verdadeiras forças, determinavam-se máximos e mínimos dessas forças, bem como eram estabelecidas as circunstâncias mais vantajosas na construção e uso das mesmas máquinas.

Com este estudo ficava completo a parte do programa da cadeira de Phoronomia que tinha por objecto o movimento dos corpos sólidos. Seguia-se o estudo do movimento dos corpos fluidos, no qual se fazia uso dos mesmos princípios aplicados aos sólidos, combinados com um 
princípio particular, aplicável aos fluidos. Este princípio particular tinha origem na experiência e era aplicável a todas as espécies de fluidos da natureza, e referia-se à pressão igual que os fluidos faziam para todas as partes. Este ramo da ciência do movimento, aplicada aos fluidos, era constituída pelos seguintes temas:

\section{- Teoria da Phoronomia dos fluidos.}

Considerando o conceito de pressão, desenvolvia-se o tratamento da gravitação dos licores sobre o fundo e paredes dos vasos que os continham. Determinavam-se as condições observáveis para que os vasos pudessem conter os líquidos, sem se danificarem. Estabeleciam-se as condições de equilíbrio dos fluidos entre si, e com os sólidos que neles fossem colocados. Procedia-se ao estudo do movimento das águas por diferentes canais, e por quaisquer orifícios de vasos cheios até qualquer altura. Fazia-se referência aos efeitos da resistência dos fluidos ao movimento dos corpos de qualquer espécie e com qualquer configuração. Neste capítulo eram também estudados os movimentos de oscilação dos corpos flutuantes, e de tudo o mais que pertencesse à teórica completa de todos os ramos das ciências que se reduzissem à Phoronomia dos fluidos.

\section{- Arquitectura Hidráulica e das Máquinas.}

Neste capítulo eram particularmente tratados os assuntos relativos ao problema da condução e elevação das águas. Este estudo tinha por finalidade o desenvolvimento dos conhecimentos aplicáveis em benefício da Agricultura, particularmente para a fertilidade dos solos. Era dado um especial tratamento ao estudo dos modelos das máquinas e artifícios célebres, que ao longo da história tiveram o seu desenvolvimento.

\section{- O movimento da luz.}

A natureza da luz, sendo considerada uma questão obscura, não fazia parte do objecto de estudo na cadeira de Phoronomia. Três princípios fundamentais constituíam a base de desenvolvimento deste domínio de conhecimento. Estes princípios tinham os seguintes enunciados: 
I. Que a luz se propaga por uma linha recta.

II. Que se reflecte por um ângulo igual ao ângulo de incidência.

III. Que ao entrar, e sair por meios diáfanos de diferente densidade se refracta por certas leis, que pela experiência se determinam.

Estes três princípios serviam de base para os dois ramos da ciência que tinha por objecto de estudo o movimento da luz: Dioptrica, e Catoptrica. Todo o restante corpo de conhecimentos destas ciências se limitava ao Cálculo e à Geometria. Considerando as respectivas situações específicas, estudavam-se as circunstâncias do movimento da luz, qualquer que fosse a natureza da superfície onde se dava a reflexão, e a diversidade dos meios em que se refractava. Considerando a especificidade dos meios explicava-se a diferente rafrangibilidade dos meios, a qual dava origem ao fenómeno da manifestação das cores, para além de outros fenómenos admiráveis. A utilidade destes conhecimentos era evidenciada pela aplicação destas doutrinas na construção dos diversos tipos de instrumentos ópticos. Também estava contemplado neste estudo a Theorica Sublime das Objectivas Achromaticas, que pela Analyse tinha recebido nos últimos tempos um importante desenvolvimento.

Na Optica propriamente dita examinavam-se as Leis da Visão. Segundo se observava nos Estatutos, os conhecimentos que se tinham sobre este assunto eram ainda pouco consistentes. Este ramo do estudo do movimento da luz carecia ainda de princípios claros e demonstrados, sobre os quais a Mathematica tornasse possível formar uma ciência completa, tal como se observava na Dioptrica e na Catoptrica. Deste modo, não se devia dissimular a insuficiência dos raciocínios através dos quais se pretendiam explicar os meios pelos quais os olhos tinham a percepção da distância, grandeza aparente, lugar dos objectos, grandeza das imagens que se representavam nos espelhos planos, côncavos e convexos. Atendendo às limitações existentes, afigurava-se importante a referência sobre o que neste domínio do conhecimento ainda estaria por fazer, apontando, se possível, alguns meios por onde se pudessem descobrir os seus princípios genuínos. 


\section{- Teórica dos sons.}

Também a Acustica, ou Theorica dos sons, estava limitada a um reduzido número de situações físicas que eram susceptíveis do Cálculo. Nestes casos o estudante aprendia as aplicações do método de calcular as vibrações das cordas sonoras, atendendo à sua tensão, espessura e comprimento. Se este estudo era quantificável, o mesmo não se observava no que se relacionava com a razão porque certas combinações de sons eram agradáveis, e outras desagradáveis ao ouvido humano. Sobre este assunto não estavam claramente definidos os seus princípios fundamentais, como também as explicações que neste ramo da Física se costumavam dar eram consideradas manifestamente insuficientes.

\section{- Arquitectura Civil, Naval e Militar.}

Embora estes estudos não pertencessem à classe das Sciencias Fysico-Mathematicas, por se basearem em regras consideradas arbitrárias, as quais deveriam ser ensinadas numa cadeira extraordinária, os Estatutos estabeleciam que na cadeira do terceiro ano do Curso Mathematico fossem incluídos, nos lugares competentes, os problemas mecânicos relativos às ditas artes. Como exemplos de aplicação dos conhecimentos adquiridos, deveriam abordar-se questões como a determinação do equilíbrio das abóbadas com os pés direitos, estudo do sólido da menor resistência, bem como outros exemplos de natureza semelhante. As novas regras que resultassem das soluções matemáticas encontradas para problemas específicos deveriam passar a ser do conhecimento dos arquitectos e construtores, por forma a evitar a utilização das regras arbitrárias, regularmente utilizadas por falta de conhecimento das competentes soluções matemáticas. Os Estatutos de 1772 consideravam que: ${ }^{56}$

... as referidas Artes não poderáõ chegar ao estado de Sciencias, em quanto não forem dirigidas pela Mathematica em todas as suas Operações; exceptuando a decoração, que depende do gosto, e nunca poderá regular-se por Cálculo, nem por Geometria.

56 Idem p. 188. 


\section{A Astronomia Fysico-Mathematica como um ramo da Pboronomia}

Após o estudo dos movimentos dos corpos, aplicado aos objectos da Fysica Sublunar, feito no terceiro ano do Curso Mathematico, os estudantes deveriam ouvir, no quarto ano, as lições de Astronomia Fysico-Mathematica. Esta cadeira era um ramo da Phoronomia, aplicada ao movimento dos astros. Apenas a sua vastidão justificava que o seu estudo fosse integrado como uma cadeira independente no plano geral do Curso Mathematico.

O programa da cadeira de Astronomia Fysico-Mathematica tinha como objectivo a formação teórica e prática. O professor deveria começar as suas lições apresentando um substanciado resumo histórico, salientando as épocas mais notáveis neste domínio do conhecimento humano. Para que os estudantes ficassem habilitados para a aplicação dos métodos matemáticos indispensáveis, a este capítulo introdutório seguiam-se as lições de Trigonometria Esferica. Neste capítulo eram ensinados os princípios fundamentais deste ramo da Geometria, e simultaneamente eram apresentadas as noções gerais relativas à Esfera.

O estudo próprio da Astronomia desenvolvia-se tendo em atenção os seguintes objectivos:

- que os estudantes adquirissem o conhecimento dos fenómenos, deduzido da observação;

- compreendessem a razão física dos fenómenos;

- estabelecessem as regras de cálculo necessárias para quantificar os fenómenos num determinado instante, em consequência da sua razão física.

Em relação à metodologia, os Estatutos Pombalinos indicavam como possíveis duas estratégias de ensino nesta cadeira: ${ }^{57}$

O Primeiro consiste em dipôr os conhecimentos já descubertos, e averiguados, pela ordem Doutrinal, e Synthetica; de sorte, que façam hum encadeamento natural; e se apresentem ao entendimento do modo mais facil, e ventajoso. O Segundo consiste em seguir os passos dos mesmos

57 Idem p. 190-191. 
Inventores; ajuntando primeiro as Observações de todos os Fenomenos; e entrando depois na indagação das causas delles, pela mesma cadeia de tentativas, e raciocinios, por onde se chegou, ou podia chegar aos verdadeiros conhecimentos, que hoje possuimos.

Quanto às vantagens e inconvenientes dos dois métodos, e procurando definir aquele que deveria ser preferencialmente utilizado, considerava-se que:58

Sem embargo porém de que resultariam grandes ventagens de conduzir os Estudantes pelo methodo dos Inventores, como se elles mesmos houvessem de crear a Astronomia; com tudo sendo este methodo mais longo, e dilatado; e tirando-se da Lição da Historia desta Sciencia as ventagens, que delle podiam resultar: O Lente seguirá o Primeiro dos referidos methodos nas suas Lições; presentando os conhecimentos Astronomicos de modo, que os Discipulos, ajudados das luzes adquiridas nos Annos precedentes, possam com a maior brevidade fazer huma descripção exacta de todos os Astros; e estabelecer methodicamente pela razão, e observação as Leis, e Regras dos seus movimentos, com tal precisão, que em qualquer instante dado de qualquer tempo, passado, ou futuro, possam determinar o ponto do Ceo, onde se ha de achar qualquer Astro, sendo observado de qualquer parte do Universo.

A parte da Astronomia dependente da observação encontrava-se muito aperfeiçoada. Para além do desenvolvimento instrumental, que permitiu o progressivo aperfeiçoamento das técnicas de observação, também a Fysica contribuía para uma mais completa interpretação dos fenómenos astronómicos. Sendo assim, o professor não poderia abster-se de ensinar que os movimentos planetários resultavam da acção de uma força central dirigida para o Sol, e variável na razão duplicada inversa das distâncias ao centro, combinada com outra força uniforme de projecção, impressa desde o princípio do mesmo movimento. Sendo definitivamente provado 
que o Sol era o centro dos movimentos planetários, e considerando o critério de simplicidade com que os fenómenos eram interpretados, o estudo dos astros deveria ter início pela Astronomia Solar, supondo que o observador se encontrasse no Sol. Após este estudo era desenvolvida uma análise dos fenómenos, quando observados da Terra, ou de qualquer outro ponto do Universo.

Um pormenorizado estudo das estrelas fixas tornava possível a definição de referências, servindo de pontos fixos e de termos de comparação, para observar e determinar os movimentos angulares de todos os planetas. Os estudos dos movimentos planetários eram feitos determinando-se, por observação, as revoluções periódicas, direcção, velocidade e irregularidades particulares de cada um dos planetas conhecidos. Estas observações permitiam reunir os elementos necessários, que combinados com os princípios mecânicos, tornavam viável a determinação das trajectórias dos planetas. Nos Estatutos pode ler-se que:59

A estes fins mostrará a solução do Problema de Kepler; e dará o Methodo, e Regras do Cálculo: Para reduzir a Anomalia média à verdadeira nas Orbitas Ellipticas: Ajuntando as reflexões necessarias sobre as modificações, que devem padecer as Leis dos movimentos Planetarios, procedidas de quasquer variações accidentaes nas duas forças, de que resultam os mesmos movimentos. Do mesmo modo tratará dos Fenomenos do movimento dos Cometas vistos desde o Sol.

Após o estudo do movimento dos astros, descritos num sistema heliocêntrico, tinham início as lições onde os fenómenos eram descritos num sistema de referência geocêntrico. Eram analisadas as diversas aparências que resultavam do movimento diurno da Terra, do seu movimento anual, da combinação de ambos, da posição do observador em diferentes locais sobre o globo terrestre, bem como da refracção da luz na atmosfera terrestre. Os conhecimentos adquiridos habilitavam o estudante no domínio dos métodos de correcção das observações e da sua redução às

59 Idem p. 192. 
que seriam feitas por um observador que utilizasse como referência o Sol. Para o efeito, o lente deveria apresentar aos seus discípulos os melhores métodos para estabelecer os Elementos da Theorica do Movimento da Terra, bem como de todos os outros planetas reduzidos ao plano da eclíptica. Os estudantes deveriam saber aplicar com eficácia as regras de cálculo necessárias para determinar as longitudes e latitudes, tanto heliocêntricas, como geocêntricas. Este estudo era extensível ao movimento dos cometas.

Para além do movimento de translação, ensinavam-se os aspectos relativos ao movimento diurno, ou rotação dos planetas em geral, sendo referidos os fenómenos observados e as consequências resultantes. A caracterização dos movimentos dos planetas secundários fazia-se, considerando a descrição a partir do Sol, seguida depois do respectivo planeta principal, e finalmente da Terra. Eram apresentadas as regras de cálculo relativas à determinação do lugar dos satélites de Júpiter e de Saturno, para qualquer instante dado. Entre os planetas secundários, merecia especial desenvolvimento a Theorica da Lua, considerada a mais difícil e a mais importante. O tratamento desenvolvido do movimento da Lua fazia-se examinando os elementos principais, decorrentes da observação, referindo-se pormenorizadamente às características do seu movimento orbital. Eram explicados os aspectos relacionados com a sua força central, dirigida para a Terra, que actuava simultaneamente com a força solar, a qual tinha por efeito desviá-la da trajectória elíptica, originando irregularidades no seu movimento. Os dados relativos a estas forças eram combinados com os da figura da Terra, para uma explicação do fenómeno da precessão dos equinócios e da mutação do eixo terrestre. Explicava-se que destes fenómenos resultavam duas pequenas variações na obliquidade da eclíptica, uma uniforme, outra periódica, bem como algumas irregularidades na posição dos astros. Para uma completa compreensão e caracterização do movimento da Lua, procedia-se ao estudo do Problema dos três Corpos, explicando-se do modo mais elementar os métodos de aproximação, com a respectiva aplicação ao caso do movimento do satélite da Terra. A importância da aplicação da Fysica no domínio de conhecimentos da Astronomia era evidenciada, deduzindo-se do único 
princípio da Gravitação Universal, não somente os argumentos de que dependiam todas as equações, como também todas as equações que pela sua mútua complexidade não podiam ser deduzidas das observações.

Ainda sobre o movimento dos planetas secundários em geral, era feito um tratamento particular dos respectivos eclipses, descritos como se fossem observados do seu planeta principal, ou de qualquer outra parte do Universo. As fases dos eclipses do Sol e da Lua eram objecto de um tratamento desenvolvido, sendo especialmente referido o seu uso para se determinarem as longitudes geográficas. As ocultações das estrelas fixas pela Lua, e as passagens de Vénus e Mercúrio pelo disco solar eram igualmente objecto de um estudo pormenorizado.

Este extenso e completo programa de Astronomia tinha duas componentes: a teórica, e a prática. Com efeito, nos Estatutos Pombalinos afirmava-se que: 60

Em todo este Curso se ajuntará sempre a Theorica com a Prática: Fazendo-se adquirir aos Ouvintes o habito, e promptidão necessaria nos Calculos Astronomicos, e na Prática das Observações. Para estes fins se mostrará o uso dos Instrumentos no Observatorio nos dias, e horas, que parecerem mais convenientes. E quando houverem de se fazer algumas observações, se nomearáõ por turno aquelles dos Discipulos, que haõ de assistir ao sobredito Professor. Os quaes acudirão diligentemente ao tempo determinado. Os que faltarem, sem causa justa, perderão dez cruzados para a Arca da Faculdade.

Para o cumprimento da parte prática do programa da Cadeira de Astronomia Fysico-Mathematica ficou ordenado que se mandasse construir um edifício com condições ideais para a instalação do Observatório Astronómico. Após a sua conclusão deveria ser equipado com a melhor instrumentação proveniente dos mais qualificados fabricantes. A importância deste grande investimento justificava-se, uma vez que: ${ }^{61}$

\footnotetext{
60 Idem p. 195.

61 Idem p. 213.
} 
As ventagens, que resultam de se cultivar efficazmente a Astronomia, com todas as mais partes da Mathematica, de que ella depende, são de tão grande ponderação, e de consequencias tão importantes ao adiantamento geral dos conhecimentos humanos; e á perfeição particular da Geografia, e da Navegação; que tem merecido em toda a parte a attenção dos Soberanos, fazendo edificar Observatorios magníficos, destinados ao progresso da Astronomia, como Sciencia necessaria para se conseguir o conhecimento do Globo terrestre; e se terem nas mãos as chaves do Universo.

$* * *$

Tendo como referência os conteúdos programáticos das cadeiras que faziam parte do programa de estudos das Faculdades de Filosofia e de Mathematica, bem como tendo em consideração o conjunto de cadeiras que os estudantes das duas Faculdades deveriam frequentar, pode afirmar-se que no âmbito das ciências físico-matemáticas a Reforma Pombalina da Universidade de Coimbra se caracterizou por uma importante complementaridade pedagógica e científica. Este aspecto viria a ser marcante na evolução observada em ambas as Faculdades ao longo de todo a século XIX. Muito cedo se começou a sentir a necessidade de um profundo desenvolvimento da formação científica dos estudantes, que melhor se ajustasse ao intenso progresso científico que caracterizou o século XIX. Para um acompanhamento adequado deste desenvolvimento surgiram várias propostas de desdobramento das cadeiras, cuja vastidão do domínio de conhecimentos já não podiam ser contemplados em apenas uma cadeira anual. Estas propostas tiveram particular incidência nas cadeiras de Fysica Experimental e de Phoronomia. Foram várias as reformas que ocorreram nos cursos de Filosofia e de Matemática, mas todas com um denominador comum: na Faculdade de Filosofia os estudantes eram preparados na vertente experimental da sua formação, assumindo especial importância a aprendizagem feita na cadeira de Fysica Experimental, enquanto a formação teórica mais aprofundada era obtida na cadeira de Phoronomia ou, posteriormente, nas cadeiras de ciências físico-matemáticas em que esta se viria a desdobrar. 
(Página deixada propositadamente em branco) 


\section{Série Investigação}

Imprensa da Universidade de Coimbra

Coimbra University Press

2014

- U

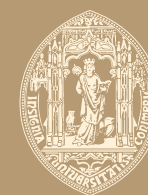

C •

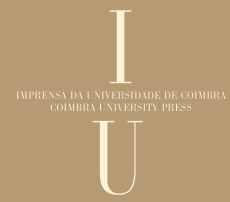

